\title{
Plant Lectins Targeting $O$-Glycans at the Cell Surface as Tools for Cancer Diagnosis, Prognosis and Therapy
}

\author{
Guillaume Poiroux ${ }^{1}$, Annick Barre ${ }^{2}$, Els J. M. van Damme ${ }^{3}$, Hervé Benoist ${ }^{2}$ and Pierre Rougé $^{2, *}$ \\ 1 Institut National de la Santé et de la Recherche Médicale, Unité Mixte de Recherche, Centre de Recherche en \\ Cancérologie de Toulouse, 31037 Toulouse, France; guillaume.poiroux@inserm.fr \\ 2 Unité Mixte de Recherche, 152 PharmaDev, Institut de Recherche et Développement, Faculté de Pharmacie, \\ 35 Chemin des Maraîchers Université Paul Sabatier, 31062 Toulouse, France; \\ annick.barre@univ-tlse3.fr (A.B.); herve.benoist@ird.fr (H.B.) \\ 3 Department of Molecular Biotechnology, Faculty of Bioscience Engineering, Ghent University, \\ Coupure links 653, B-9000 Ghent, Belgium; ElsJM.VanDamme@UGent.be \\ * Correspondence: pierre.rouge@free.fr; Tel.: +33-069-552-0851
}

Academic Editor: Marcello Iriti

Received: 26 May 2017; Accepted: 31 May 2017; Published: 9 June 2017

\begin{abstract}
Aberrant $O$-glycans expressed at the surface of cancer cells consist of membrane-tethered glycoproteins ( $\mathrm{T}$ and $\mathrm{Tn}$ antigens) and glycolipids (Lewis a, Lewis $\mathrm{x}$ and Forssman antigens). All of these $\mathrm{O}$-glycans have been identified as glyco-markers of interest for the diagnosis and the prognosis of cancer diseases. These epitopes are specifically detected using $\mathrm{T} / \mathrm{Tn}$-specific lectins isolated from various plants such as jacalin from Artocarpus integrifola, and fungi such as the Agaricus bisporus lectin. These lectins accommodate $\mathrm{T} / \mathrm{Tn}$ antigens at the monosaccharide-binding site; residues located in the surrounding extended binding-site of the lectins often participate in the binding of more extended epitopes. Depending on the shape and size of the extended carbohydrate-binding site, their fine sugar-binding specificity towards complex $O$-glycans readily differs from one lectin to another, resulting in a great diversity in their sugar-recognition capacity. $\mathrm{T} / \mathrm{Tn}$-specific lectins have been extensively used for the histochemical detection of cancer cells in biopsies and for the follow up of the cancer progression and evolution. $\mathrm{T} / \mathrm{Tn}$-specific lectins also induce a caspase-dependent apoptosis in cancer cells, often associated with a more or less severe inhibition of proliferation. Moreover, they provide another potential source of molecules adapted to the building of photosensitizer-conjugates allowing a specific targeting to cancer cells, for the photodynamic treatment of tumors.
\end{abstract}

Keywords: lectin; O-glycosylation; Tn antigen; T antigen; Morniga G; peanut lectin; cancer; diagnosis; prognosis; photodynamic therapy

\section{Introduction}

The malignant transformation is accompanied by profound alterations in both the $\mathrm{N}$ - and $O$-glycosylation processes in healthy cells [1-3]. In cancer cells, the aberrant $O$-glycans expressed at the cancer cell surface occur as saccharide components of membrane-bound $\mathrm{N}$-acetyl galactosamine (O-GalNAc) glycoproteins ( $\mathrm{T}$ and Tn antigen) and glycolipids (Lewis a and Lewis $\mathrm{x}$ ). The occasional sialylation of the ultimate sugar of the glycan chain introduces an additional diversity in the O-glycan repertoire expressed by cancer cells [4-12]. In addition, mucin, a heavily O-GalNAc glycosylated protein, is overexpressed and subsequently secreted by cancer cells, essentially at the last stages of the malignant progression $[13,14]$. All of these aberrant $O$-glycans may serve as potential targets to improve the diagnosis and the treatment of tumors, provided the molecular probes are available for their specific recognition [15-17]. In this respect, monoclonal antibodies that specifically recognize both the sialylated and non-sialylated $\mathrm{Tn}$ and $\mathrm{T}$ antigens have been widely used to detect malignant 
cells [18-22]. Lectins and, especially, plant and fungal lectins that display a $\mathrm{T} / \mathrm{Tn}$-specificity, consist of another source of potential molecular probes available for the specific recognition of tumor cell O-glycans [23]. During the last decade, the list of $\mathrm{T} / \mathrm{Tn}$-specific lectins isolated and characterized from plants and fungi, has increased tremendously, making new lectins available as potential molecular probes for the recognition of cancer cells (see Table 1). In parallel, new insights have been obtained on the immunotoxicity of plant lectins toward cancer cells and their role in the reinforcement of the innate (anti-cancer) immunity (see [24] for a review), which assign plant and fungal lectins as valuable tools for the diagnosis and treatment of cancer. Here, we present an updated review on the potential use of plant and fungal lectins as probes for both the diagnosis, the prognosis, and the treatment of cancer.

\section{Altered O-Glycan Patterns Expressed by Cancer Cells}

Alterations to surface properties of cancer cells account for their aptitude to aggregate and, thus, improve the invasive and metastatic capacity of many tumors. Changes of the surface properties of cancer cells essentially depend on the overexpression of aberrant $\mathrm{O}$ - and $\mathrm{N}$-glycans, which occur as membrane-associated glycoproteins and glycolipids exposed at the cell surface [1]. Due to their high occurrence in most cancer cells, alterations of the $O$-glycosylation have been deeply investigated since the characterization of the so-called $\mathrm{T}$ antigen (Thomsen-Friedenreich) and Tn antigen [4]. The most frequent aberrant $O$-glycans expressed at the surface of cancer cells consist of Tn antigen $(\alpha 1 \rightarrow \mathrm{Ser} / \mathrm{Thr})$, $\mathrm{T}$ antigen (Gal $\beta 1 \rightarrow 3$ GalNAc $\alpha 1 \rightarrow$ Ser/Thr), Lewis a (Gal $\beta 1 \rightarrow 3$ [Fuc $\alpha 1 \rightarrow 4$ ]GlcNAc $\beta 1 \rightarrow R$ ) and Lewis $\times(\mathrm{Gal} \beta 1 \rightarrow 4[\mathrm{Fuc} \alpha 1 \rightarrow 3] \mathrm{GlcNAc} \beta 1 \rightarrow \mathrm{R})$ antigens, and an oncofetal glycotope, the Forssman pentasaccharide antigen (GalNAc $\alpha 1 \rightarrow 3 \mathrm{GalNAc} \beta 1 \rightarrow 3 \mathrm{Gal} \alpha 1 \rightarrow 4 \mathrm{Gal} \beta 1 \rightarrow 4 \mathrm{Glc}$ ) [1-3] (Figure 1). All of these glycotopes also exist as sialylated forms, with Neu5Ac $\alpha 2 \rightarrow 3$-linked to the ultimate Gal ( $T$ antigen, Lewis a and Lewis $x$ antigen) or GalNAc residue (Tn antigen) (Figure 1). Except for the Forssman antigen, other antigens relate to the blood group antigen precursors, $\mathrm{MN}$ antigens for $\mathrm{Tn}$ and $\mathrm{T}$ antigen, $\mathrm{ABH}$ antigens for Lewis a and Lewis $\mathrm{x}$ antigen. Finally, malignancy is often associated with the overproduction of secreted and membrane-tethered mucins [25], glycoproteins which consist of tandemly repeated Tn antigen units (PDB code 2MK7) (Figure 2).

All of these membrane-associated $O$-glycans aberrantly expressed in cancer cells represent cancer glyco-markers that may be recognized using specific monoclonal antibodies or $\mathrm{T} / \mathrm{Tn}$-specific lectins as probes. In this respect, plant and fungal lectins displaying a functional $\mathrm{T} / \mathrm{Tn}$-specificity mimic the galectins, which innately occur in humans and other mammal organisms as endogenous recognition factors for the aberrant $O$-glycans exposed at the tumor cell surface [26]. However, beyond this apparently functional similarity, exogenous plant lectins and endogenous galectins readily differ from the monoclonal antibodies used as $O$-glycan probes by the topography and the molecular mechanism occurring at their $O$-glycan-binding sites. 


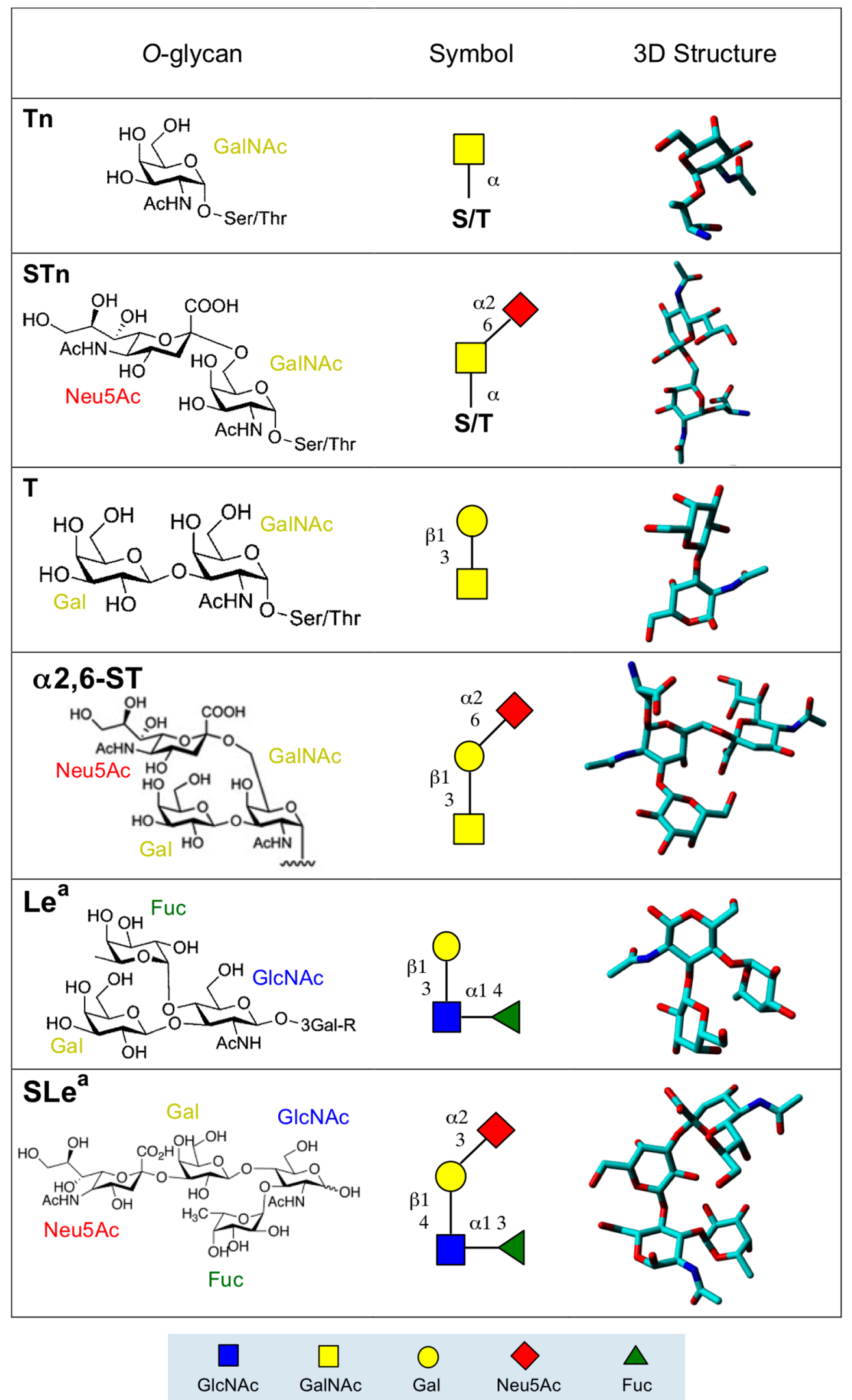

Figure 1. Molecular structure of the $O$-glycans expressed on the cancer cell surface. T antigen also occurs as a component of the soluble mucin excreted by both healthy and cancer cells. GlcNAc, $N$-acetyl D-glucosamine; GalNAc, N-acetyl D-galactosamine; Gal, D-galactose; Neu5Ac, sialic acid; Fuc, L-fucose. 


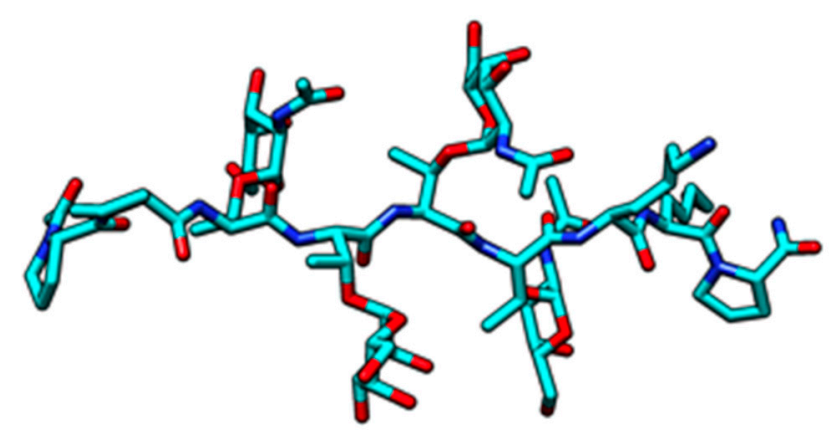

Figure 2. Cartoon showing the clustering of Tn antigens along the peptide chain of the tetra-O-GalNAc glycosylated mucin sequence of the human $\alpha$-dystroglycan mucin domain peptide (residues 419-PPTTTTKKP-427) (PDB code 2MK7; Borgert A, Foley L, Live D). Cartoon drawn with Chimera [27].

\section{Plant Lectins Specific for $T$ and Tn Antigens}

Thus far, up to forty-six lectins isolated from different families of plants and fungi have been characterized as $\mathrm{T} / \mathrm{Tn}$-specific lectins (Table 1). Plant lectins have originated from species belonging to a few predominant families such as Fabaceae (BPA from Bauhinia purpurea, Gs I-A 4 from Griffonia simplicifolia, PNA from peanut, SBA from soybean, VVA B4 from Vicia villosa, WBL from the winged bean Psophocarpus tetragonolobus, and WFA from Wisteria floribunda), Caprifoliaceae (SNA-I, SNA-II and SNA-IV from Sambucus nigra), Lamiaceae (SSA from Salvia sclarea, SHA from S. hominum, and SbA from S. bogotensis), Euphorbiaceae (ricin and RCA-I from Ricinus communis) and Moraceae (jacalin and the jacalin-related lectin MPA from Maclura pomifera). A few T/Tn-specific lectins such as SNA-I and SNA-V from the elderberry Sambucus nigra, BGSL from the bitter gourd (Momordica charantia), and the galactose-specific lectin and ricin from the castor bean (Ricinus communis) correspond to chimerolectins composed of a toxic A-chain covalently linked to a B-chain displaying the T/Tn-specificity [28]. Fungal lectins (ABL from Agaricus bisporus, AAL from Agrocybe aegerita and XCL from Xerocomus chrysenteron) with a T/Tn-specificity belong exclusively to the group of Basidiomycota mushrooms. Although most of the so-called $\mathrm{T} / \mathrm{Tn}$-specific lectins readily react with both $\mathrm{T}$ and $\mathrm{Tn}$ antigens, $\mathrm{T}$ and $\mathrm{Tn}$ consist of very distinct antigens that arise by different mechanisms and in different cancerous tissues. In addition, plant lectins specific for T and/or Tn antigens also interact with $\alpha$-D-Gal and the Gal-specificity of some T/Tn-specific lectins such as jacalin from Artocarpus integrifolia seeds is as potent and even stronger than that displayed for both $T$ and Tn antigens [29,30]. This stronger interaction with $\alpha$-D-Gal depends on its fixation to the primary binding site of the lectin via a dense network of nine hydrogen bonds, as shown from the crystallographic complex of jacalin with galactose (PDB code 1UGW) [31].

The carbohydrate-binding site (CBS) of plant and fungal lectins consists of a carbohydrate-binding pocket, the so-called monosaccharide-binding site, responsible for the binding of simple sugars via a network of hydrogen bonds linking the sugar to a few polar residues forming the binding pocket [23]. Usually, additional non-polar stacking interactions with aromatic residues located in the close vicinity of the monosaccharide-binding site, complete the anchorage of simple sugars to the site. The area surrounding the monosaccharide-binding site delineates an extended carbohydrate-binding site, which also participates in the binding of more complex glycans by creating additional H-bonds and stacking interactions with other sugar units of the glycan chain. In fact, the CBS consists of a monosaccharide-binding site embedded in a more extended binding area forming the extended glycan-binding site. Due to the extreme variation in the shape and size of the extended CBS from one lectin to another, the tight association of the monosaccharide-binding site and extended binding site, offers to plant and fungal lectins an extremely versatile tool for the specific recognition of complex $O$-glycan chains. Such a versatility explains why different lectins displaying the same broad sugar specificity, i.e., the recognition of a unique simple sugar such as Gal, GalNAc or Man, often differ by 
their ability to specifically recognize more complex glycans, depending on different shape and size of their extended CBS [23].

Table 1. List of the plant (P) and fungal (F) Tn/T-specific lectins.

\begin{tabular}{|c|c|c|c|}
\hline Plant/Fungus & Lectin & Specificity & References \\
\hline Abrus precatorius $(\mathrm{P})$ & APA & $\mathrm{T}$ & [32] \\
\hline Agaricus bisporus (F) & $\mathrm{ABL}$ & $\mathrm{T}$ & {$[33,34]$} \\
\hline Agrocybe aegerita (F) & AAL & $\mathrm{ST} / \mathrm{T}$ & [35] \\
\hline Agropyrum repens (P) & ARL & $\mathrm{T}$ & [36] \\
\hline Amaranthus caudatus (P) & Amaranthin & $\mathrm{T} / \mathrm{Tn}$ & {$[37,38]$} \\
\hline Amaranthus leucocarpus (P) & ALL & $\mathrm{T} / \mathrm{Tn}$ & [39] \\
\hline Arachis hypogaea $(\mathrm{P})$ & PNA & $\mathrm{ST}>\mathrm{T}>\mathrm{Tn}$ & {$[38,40,41]$} \\
\hline Artocarpus incisa $(\mathrm{P})$ & Frutalin & $\mathrm{T}$ & {$[42]$} \\
\hline \multirow{2}{*}{ Artocarpus integrifolia (P) } & Jacalin & $\mathrm{ST} / \mathrm{T} / \mathrm{Tn}$ & [43] \\
\hline & Champedak GBL & Tn of O-mucin & [44] \\
\hline Artocarpus lakoocha $(\mathrm{P})$ & ALL & $\mathrm{T} / \mathrm{Tn}$ cluster & [45] \\
\hline Bauhinia forficata $(\mathrm{P})$ & BfL & $\operatorname{Tn}$ & [46] \\
\hline Bauhinia purpurea (P) & BPA & $\mathrm{T} / \mathrm{Tn}$ cluster & [47] \\
\hline Caragana arborescens $(\mathrm{P})$ & CAA & ST, Forssman & [48] \\
\hline Codium fragile (alga) & CFA & $\mathrm{T} / \mathrm{Tn}$, Forssman & [49] \\
\hline Dolichos biflorus $(\mathrm{P})$ & $\operatorname{Tn}$ & $\mathrm{Tn}$ & [50] \\
\hline Glechoma hederacea $(\mathrm{P})$ & Gleheda & $\mathrm{T} / \mathrm{Tn}$ & [51] \\
\hline Glycine $\max (\mathrm{P})$ & SBA & Tn, mucin & [52] \\
\hline Griffonia (Bandeirea) simplicifolia $(\mathrm{P})$ & Gs I-A 4 & $\mathrm{Tn}$ & {$[53,54]$} \\
\hline Lactarius deliciosus $(\mathrm{F})$ & LDL & $\mathrm{T}$ & [55] \\
\hline Lactarius deterrimus $(\mathrm{F})$ & LDetL & $\mathrm{T}$ & [56] \\
\hline Laelia autumnalis (P) & LAL & $\mathrm{T} / \mathrm{Tn}$ & [57] \\
\hline Maclura pomifera $(\mathrm{P})$ & MPA & $\mathrm{T} / \mathrm{Tn}$ & {$[58,59]$} \\
\hline Moluccella laevis $(\mathrm{P})$ & MLL & Tn, Forssman & {$[60,61]$} \\
\hline Momordica charantia (P) & BGSL & $\mathrm{T}$ & [62] \\
\hline Morus nigra $(\mathrm{P})$ & Morniga-G & $\mathrm{Tn} / \mathrm{T}$ cluster & [63] \\
\hline Myrsine coriacea $(\mathrm{P})$ & McL & $\mathrm{Tn}$ & [64] \\
\hline Psophocarpus tetragonolobus (P) & WBL & Tn & [65] \\
\hline \multirow{2}{*}{ Ricinus communis $(\mathrm{P})$} & Ricin & $\mathrm{T} / \mathrm{Tn}$ & [66] \\
\hline & RCA-I & $\mathrm{T}$ & [67] \\
\hline Salvia bogotensis $(\mathrm{P})$ & SBL & Tn & [68] \\
\hline Salvia sclarea $(\mathrm{P})$ & SSL & Tn & [69-71] \\
\hline \multirow{2}{*}{ Salvia hominum $(\mathrm{P})$} & SHL & Tn & [72] \\
\hline & SNA & Tn cluster & [73] \\
\hline \multirow{2}{*}{ Sambucus nigra $(\mathrm{P})$} & SNA-II & Tn & [74] \\
\hline & SNA-IV & Tn & Unpublished \\
\hline Sclerotium rolfsii $(\mathrm{F})$ & SRL & Tn cluster & [75] \\
\hline Sophora japonica (P) & SJL & $\mathrm{T}$ & [76] \\
\hline Triticum vulgare $(\mathrm{P})$ & WGA & Tn cluster & {$[77,78]$} \\
\hline Vateirea macrocarpa $(\mathrm{P})$ & VML & $\mathrm{T} / \mathrm{Tn}$ & [79] \\
\hline Vicia graminea $(\mathrm{P})$ & VguL & $\mathrm{T}$ & [80] \\
\hline Vicia villosa $(\mathrm{P})$ & VVA $_{4}$ & Tn & [81] \\
\hline Viscum album $(\mathrm{P})$ & ML-I & $\mathrm{T}$ & [82] \\
\hline Wisteria floribunda $(\mathrm{P})$ & WFA & Tn & [83] \\
\hline Xerocomus chrysenteron (F) & XCL & Tn & [84] \\
\hline Ximenia americana $(\mathrm{P})$ & Riproximin & Tn cluster & [85] \\
\hline
\end{tabular}

All of the T/Tn-specific lectins consist of dimeric or tetrameric structures built up from the non-covalent association of identical monomers, except for the B-chain lectins of type 2 RIPs (abrin and ricin) which consist of a single polypeptide chain arranged in two domains. Plant and fungal Tn-specific lectins accommodate the Tn antigen in the monosaccharide-binding site, which consists of a shallow pocket located at the top of each lectin monomer or domain. The binding of Tn antigen is achieved by a network of hydrogen bonds between the oxhydryls of the GalNAc residue and a few hydrophilic amino acids. Stacking interactions between the GalNAc ring and aromatic residues located in the vicinity of the monosaccharide-binding site, complete and reinforce the binding of Tn antigen to the lectins (Figure 3). Depending on the lectins, hydrogen bonds can occur between the amino acid moiety of the Tn antigen and the CBS of the lectin (Figure 3A). Although the amino 
acid residues forming the monosaccharide-binding site of Tn-specific lectins markedly differ from one lectin to another, the binding scheme of Tn antigen to the lectins remains very similar with $\mathrm{O} 3, \mathrm{O} 4, \mathrm{O} 6$ and $\mathrm{O} 7$ of GalNAc systematically involved in H-bonds with the amino acids of the site. However, some discrepancy can occur with the number of hydrogen bonds that link the Tn antigen to the monosaccharide-binding pocket, which varies from 7 to 10, depending on the lectin (Figure 3A,C,E,G). Accordingly, the affinity toward the Tn antigen should slightly differ among the different Tn-specific lectins of plant and fungal origin. In this respect, an interesting observation was reported by Osinaga et al. [86], who showed that VVL-B ${ }_{4}$, the Tn-specific Vicia villosa lectin, binds a single Tn epitope in surface plasmon resonance spectroscopy experiments, whereas the anti-Tn moAbs 83D4 and MLS128 only recognize two consecutive Tn epitopes. These results point out the importance of Tn clusters for the correct binding of moAbs and suggest a very different Tn recognition pattern for VVLB4 and the anti-Tn moAbs. Moreover, the recent observation by [87], that some selectivity in the binding of lectins to $\mathrm{Tn}$ antigen depends on the nature of the amino acid residue (Ser or Thr) linked to $\alpha-O-G a l N A c$, brings an additional complexity to the glycan-binding mechanisms of plant lectins.

The binding of the Thomsen-Friedenreich T-antigen (Gal $\beta 1 \rightarrow 3$ GalNAc $\alpha 1 \rightarrow$ Ser $/ \mathrm{Thr}$ ) to the plant and fungal T-specific lectins looks very similar to the binding of Tn antigen (Figure 4). The disaccharide becomes anchored to the CBS of the lectins through a network of hydrogen bonds associated with non-polar stacking interactions with aromatic residues. Most of the H-bonds occur with the GalNAc residue, which occupies the carbohydrate-binding pocket of the lectins. Usually, the ultimate Gal residue of the disaccharide remains unbonded and protrudes out of the extended CBS. However, in some lectins such as the mushroom Agaricus bisporus lectin ABL (Figure 4D) and the bitter gourd (Momordica charantia) galactose-specific lectin BGSL (Figure $4 \mathrm{H}$ ), a very limited number of H-bonds can occur between the Gal residue and amino acid residues of the extended CBS. With the exception of these few lectins, the role played by the extended CBS in the binding of the disaccharidic $O$-glycans is apparently negligible.

Obviously, the binding of $\mathrm{T}$ and $\mathrm{Tn}$ antigen is restricted to the carbohydrate-binding pocket of the plant and fungal $\mathrm{T} / \mathrm{Tn}$-specific lectins. The surface area located in the neighbor of the CBS, which forms the extended carbohydrate-binding site of the lectins, does not participate in the binding of both antigens. However, the extended CBS participates in the binding of more extended $O$-saccharides, e.g., trisaccharides such as the Lewis a (Gal $\beta 1 \rightarrow 3[\mathrm{Fuc} \alpha 1 \rightarrow 4$ ] GlcNAc $\beta 1 \rightarrow \mathrm{R}$ ), and Lewis $\mathrm{x}(\mathrm{Gal} \beta 1 \rightarrow 4[\mathrm{Fuc} \alpha 1 \rightarrow 3] \mathrm{GlcNAc} \beta 1 \rightarrow \mathrm{R})$ antigen, as shown from the crystallographic complex of GS4 lectin of Griffonia simplicifolia with the methyl-glycoside of the Lewis b blood group determinant (Figure 6) [88]. Up to 18 hydrogen bonds anchor the three sugar residues of Lewis $b$ to the extended CBS of the lectin, in association with extensive non-polar stacking interactions with five aromatic residues (Y105, F108, W133, W138, and Y223). The ultimate Gal residue of the trisaccharide binds to the carbohydrate-binding pocket via four $\mathrm{H}$-bonds, whereas the remaining $14 \mathrm{H}$-bonds serve to anchor the Fuc and GlcNAc residues of the trisaccharide to amino acids located in the extended CBS. The shape and size of the extended CBS thus appears as a determinant structural feature for the recognition of extended $O$-glycans by plant lectins. In this respect, plant lectins readily differ from monoclonal antibodies used as probes for targeting the complex O-glycans ( $\geq 3$ sugar residues) of cancer cells, which usually recognize a limited portion of the O-glycan chain. 
A

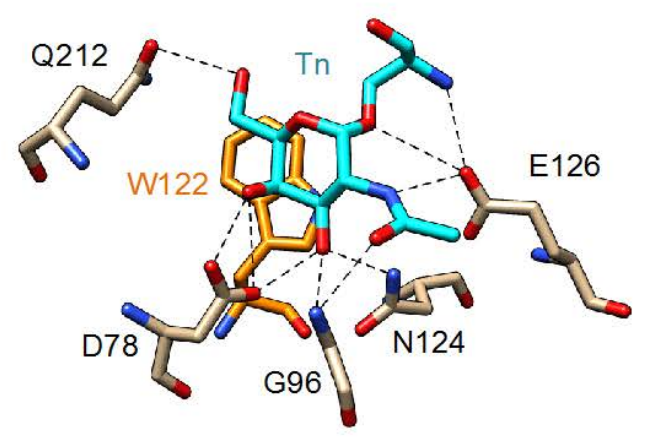

C

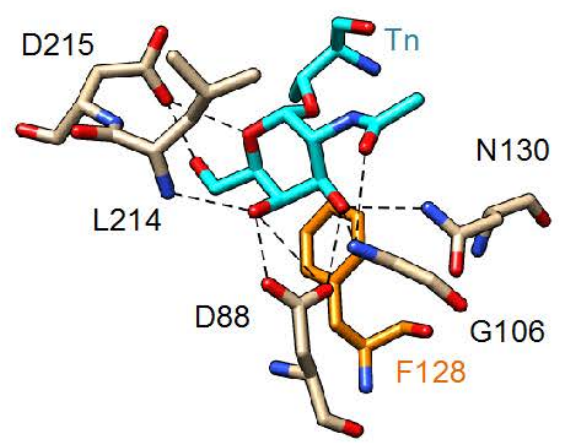

E

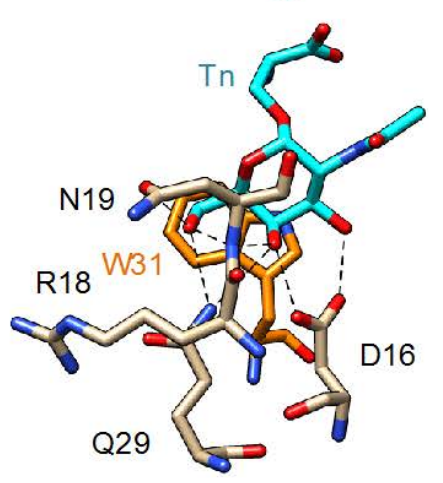

G

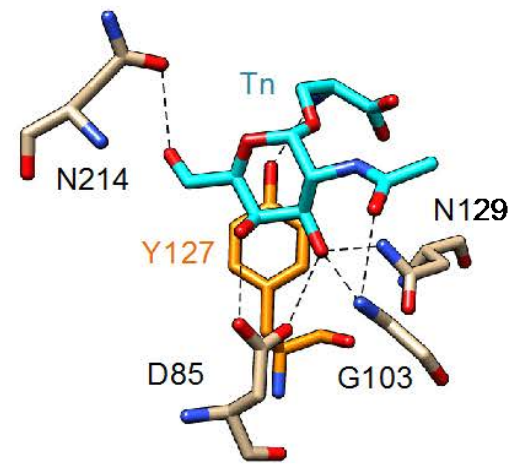

B

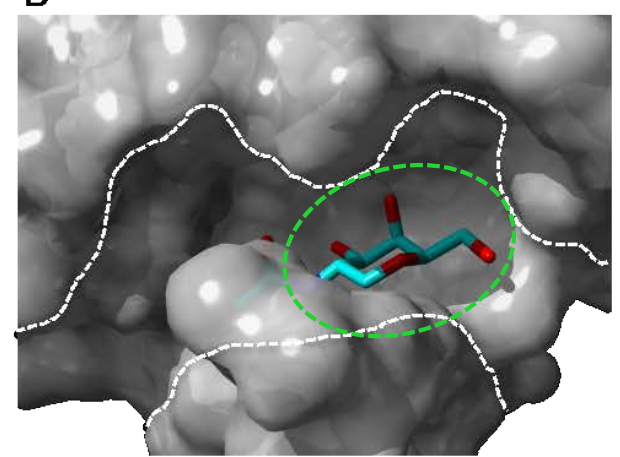

D

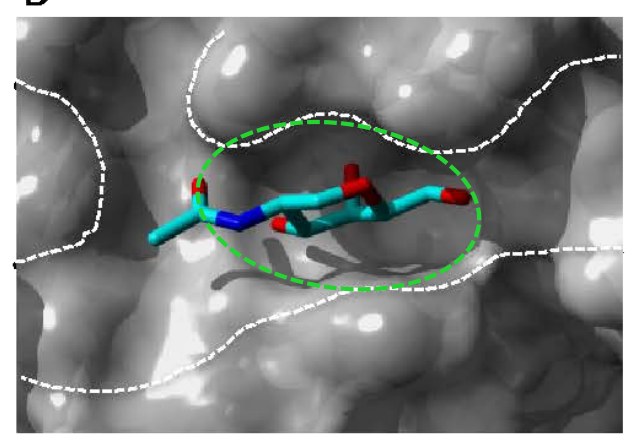

F

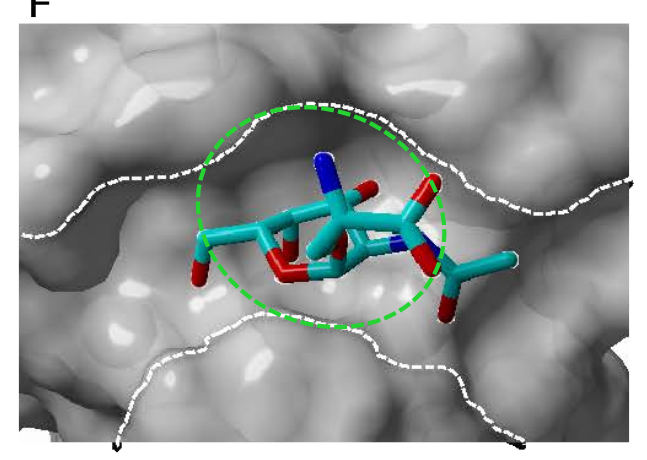

$\mathrm{H}$

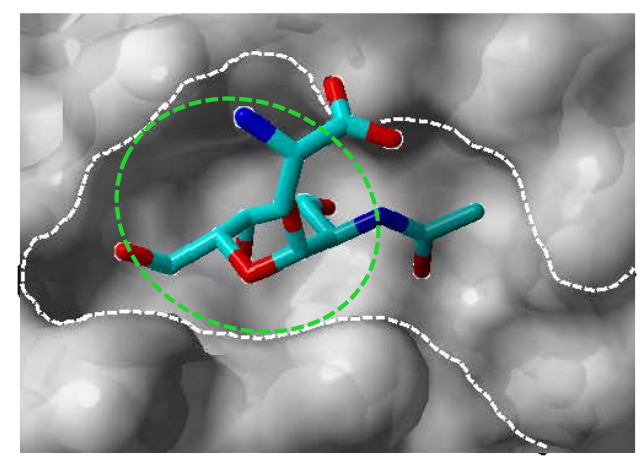

Figure 3. (A,C,E,G) Network of hydrogen bonds and stacking interactions anchoring Tn antigen (Tn) to the monosaccharide-binding site of: Bauhinia forficata BfL lectin (A) (PDB code 5T5J) [46]; soybean lectin SBA (C) (PDB code 4D69) [89]; Sambucus nigra SNA-II lectin (E) (PDB code 3CA6) [74]; and Vicia villosa VVA-B 4 lectin (G) (PDB code 1N47) [90]. Amino acid residues involved in stacking interactions with the disaccharide are colored orange; $(\mathbf{B}, \mathbf{D}, \mathbf{F}, \mathbf{H})$ Docking of Tn antigen to the monosaccharide-binding cavity (green dashed circle) of: Bauhinia forficata BfL lectin (B); soybean lectin SBA (D); Sambucus nigra SNA-II lectin (F); and Vicia villosa VVA-B4 lectin (H). The white dashed lines delineate the extended binding sites at the molecular surface of the different lectins. Cartoons drawn with Chimera [91]. 
A

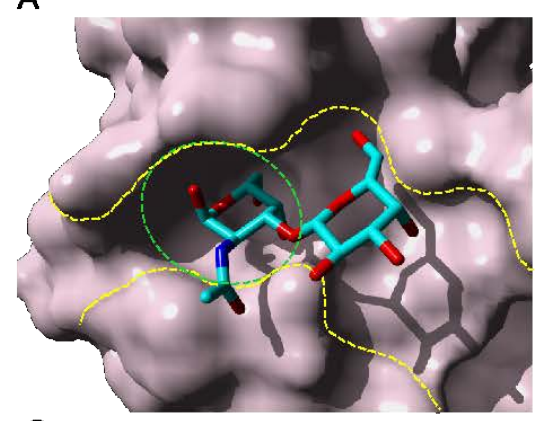

C

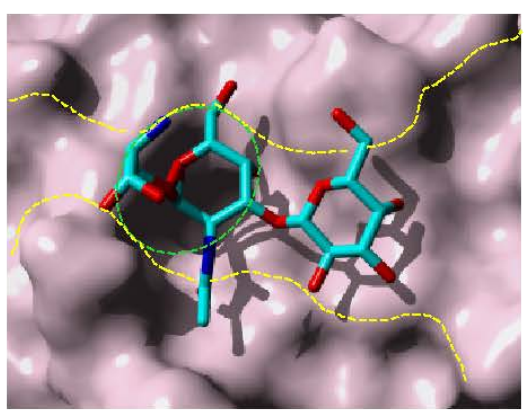

E

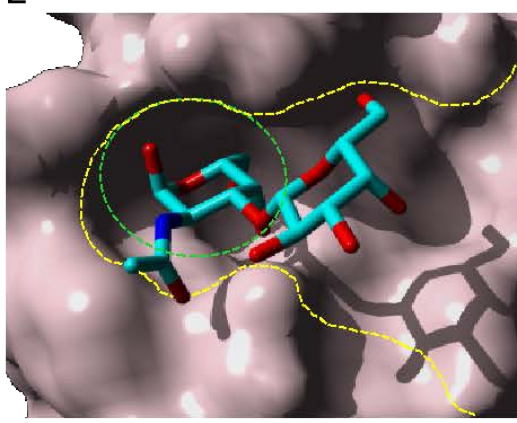

G

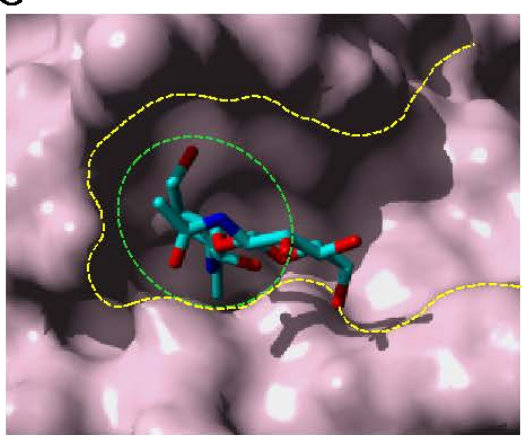

B

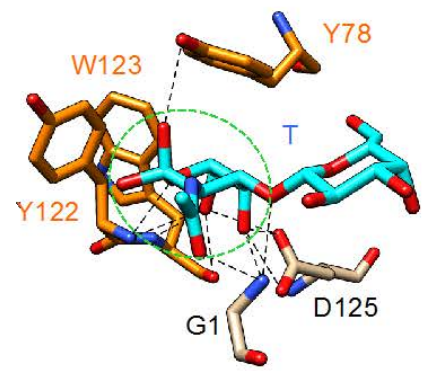

D

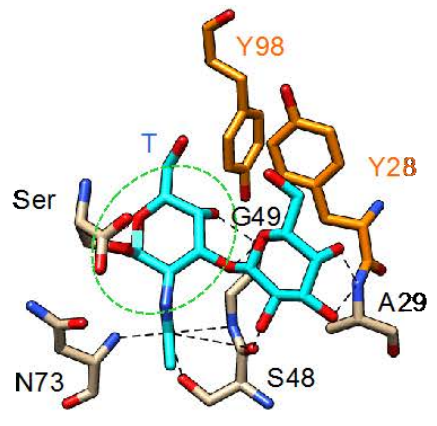

F

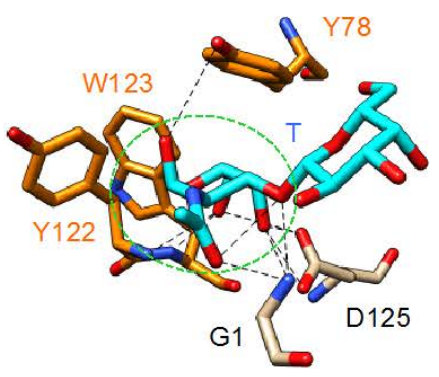

H

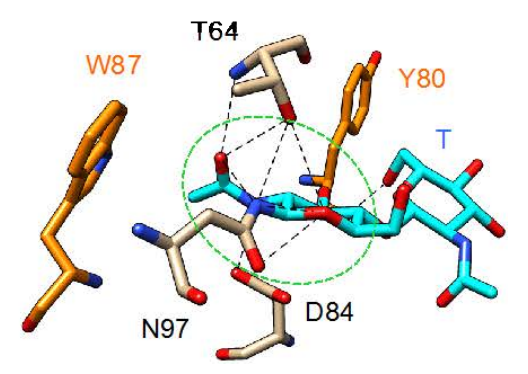

Figure 4. Monosaccharide-binding sites (green dashed circles) and extended binding sites (yellow dashed lines) of: jacalin (Artocarpus integrifolia) (PDB code 1M26) [92] (A); the mushroom Agaricus bisporus lectin ABL (PDB code 1Y2V) [34] (C); the Osage orange (Maclura pomifera) lectin MPA (PDB code 1JOT) [58] (E); and the bitter gourd (Momordica charantia) galactose-specific lectin BGSL (PDB code 4ZGR) [62] (G), in complex with T-antigen (Gal $\beta 1 \rightarrow 3$ GalNAc $\alpha 1 \rightarrow$ Ser/Thr). Network of hydrogen bonds (dashed lines) anchoring T-antigen (colored cyan) to the amino acid residues of the extended binding site of: jacalin (B); ABL (D); MPA (F); and BGSL (H). Amino acid residues involved in non-polar stacking interactions with the disaccharide are colored orange. Cartoons drawn with Chimera [91].

A similar binding pattern was shown to occur in galectin-9 complexed to the Forssman antigen (PDB code 2EAL) [93]. A network of $17 \mathrm{H}$-bonds anchors the trisaccharide moiety of the Forssman 
antigen to the carbohydrate-recognition domain of galectin-9 and seven H-bonds serve to anchor the penultimate GalNAc residue of the Forssman antigen, which occupies the monosaccharide-binding site of the galectin (Figure 5C,D). Two non-polar stacking interactions with two aromatic residues $(Y 71, W 82)$ of the extended CBS complete the binding of the Forssman antigen to the lectin. According to their capacity to accommodate extended O-glycan chains, both galectins and plant lectins similarly differ from monoclonal antibodies used as probes, which usually recognize a more limited portion of the $O$-glycan chain.
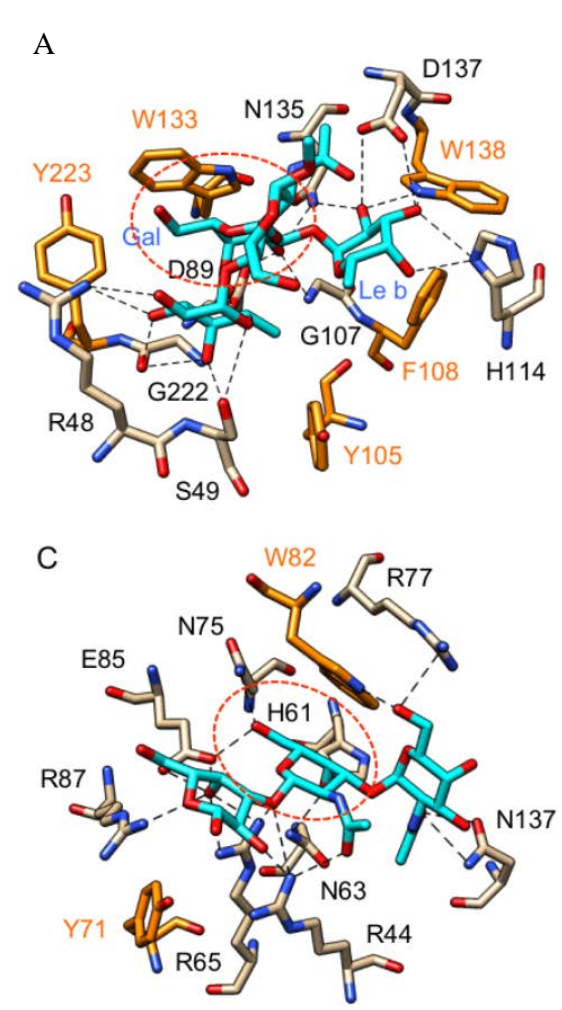

B

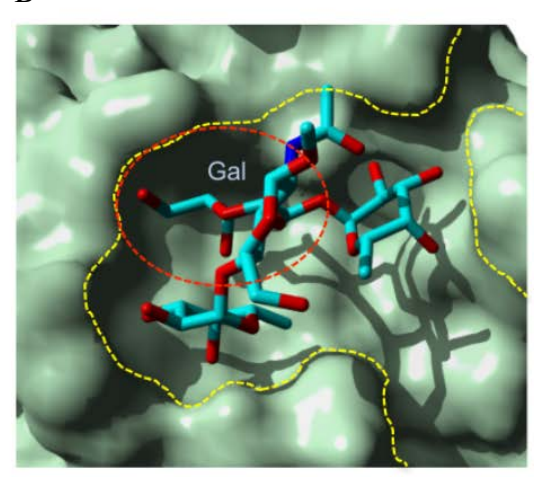

D

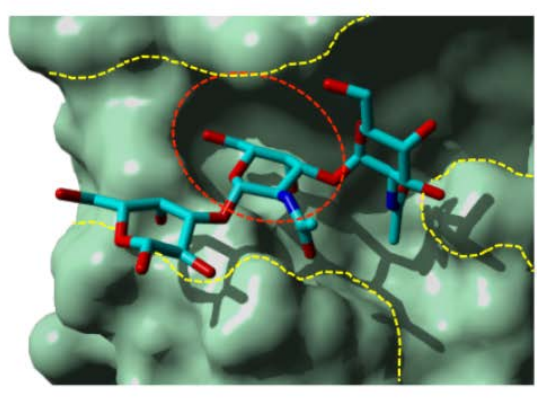

Figure 5. (A) Network of hydrogen bonds (dashed lines) anchoring Lewis b tetrasaccharide (colored cyan) to the amino acid residues of the monosaccharide-binding site (red dashed circle) of Gs I-A 4 (Griffonia simplicifolia) (PDB code 1LED) [88]. Amino acid residues involved in stacking interactions with the trisaccharide are colored orange. The Gal residue (Gal) of the Lewis b antigen occupies the monosaccharide-binding pocket of the lectin; (B) Molecular surface of Gs I-A $\mathrm{A}_{4}$ showing the monosaccharide-binding site (red dashed circle) and the extended binding site (yellow dashed lines) complexed to the Lewis b trisaccharide. The Gal residue (Gal) of the Lewis b antigen occupies the monosaccharide-binding pocket of the lectin; (C) Network of hydrogen bonds (dashed lines) anchoring the Forssman trisaccharide (colored cyan) to the amino acid residues of the carbohydrate-recognition domain of galectin-9 (PDB code 2EAL) [93]. Amino acid residues involved in stacking interactions with the trisaccharide are colored orange. The red dashed circle delineates the monosaccharide-binding site of the lectin; and (D) Molecular surface of galectin-9 showing the monosaccharide-binding pocket (red dashed circle) and the extended binding site (yellow dashed lines) complexed to the Forssman trisaccharide. The penultimate GalNAc residue (GalNAc) of the Forssman antigen occupies the monosaccharide-binding pocket of the lectin. Cartoons drawn with Chimera [91].

\section{Tn/T-Specific Lectins for Cancer Diagnosis/Prognosis}

Lectin histochemistry using $\mathrm{T} / \mathrm{Tn}$-specific lectins was previously investigated for the screening of the glycosylation changes occurring at the surface of cancer cells. Targeting of $\mathrm{T}$ and $\mathrm{Tn}$ markers by lectins proved to be an efficient tool for both the detection and prognosis of many cancers [94-96]. Especially, lectin binding pattern of peanut (PNA) and horse gram (DBA from Dolichos biflorus) 
agglutinins, were used as histochemical probes to determine the malignant status of both oral and colonic mucosa [97-102]. Moreover, the density of Tn antigen at the cell surface appeared as a good predictor of the aggressiveness in primary breast carcinoma [103]. The increase of $\mathrm{T}$ antigen occurrence in cancer cells often correlates with cancer progression and metastasis development [104]. Peanut lectin PNA strongly reacted with follicular carcinoma cells, whereas soybean agglutinin SBA, Griffonia simplicifolia lectin GSL and Vicia villosa agglutinin VVA reacted with cells lining the papillary structures in papillary carcinomas of the thyroid gland [105]. Around one third of breast cancer tumors displayed a strong binding of the mistletoe (Viscum album) lectin ML-I (VVA-1) and statistics indicated an inverse correlation between disease outcome and lectin binding [106]. Changes in O-glycosylation at different stages of differentiation of cervical intraepithelial dysplasia were investigated using different lectins [107]. The Amaranthus caudatus T/Tn-specific amaranthin, showed an increased reactivity towards dysplasia cells at stage II whereas SBA (Tn-specific soybean lectin) and GS4 (Tn-specific Griffonia simplicifolia lectin), did not discriminate among the different stages of dysplasia cells and normal tissue cells. The epithelial mesenchymal transition of HGF-treated Huh7 hepatocellular carcinoma cells is associated with a decreased affinity for a panel of $\mathrm{T} / \mathrm{Tn}$-specific lectins including ACL (Amaranthus caudatus), BPL (Bauhinia purpurea), jacalin, SBA (soybean) and SNA (Sambucus nigra) [108]. These results imply that glycan structures containing $\mathrm{T}$ and $\mathrm{Tn}$ antigens exposed at the cell surface of hepatocellular carcinoma cells are drastically reduced during the epithelial mesenchymal transitions of the cells, suggesting a pivotal role for the cell surface $O$-glycan transformations in tumor metastasis.

The use of plant and fungal lectins as cancer biomarkers has been greatly improved by the recent introduction of the glycoprotein-microarray and lectin-microarray technologies [109-116]. Glycoprotein-microarray technology consists of glycan structures isolated from the tumor cell surface, arrayed on micro-slides, and subsequently probed with individual lectins (Figure 6A). In the lectin-microarray technology, a set of different lectins is spotted on micro-slides and subsequently probed with membrane glycoproteins isolated from the tumors (Figure 6B). In both technologies, a fluorescently labeled antibody allows the recognition of the molecules used as probes. Both approaches allow screening of a number of tumor samples and may be used for the early diagnosis of cancer, and the follow up of tumor progression and their recurrence [115].

A

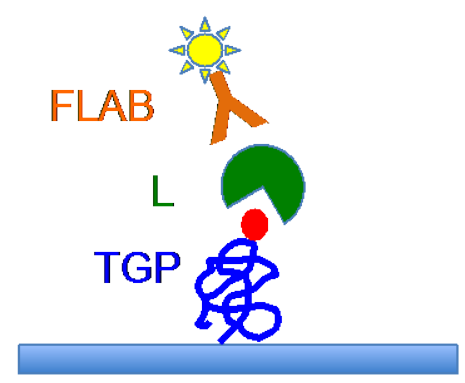

B

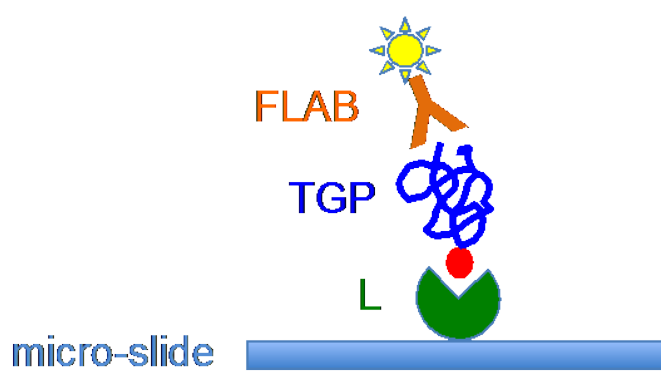

Figure 6. (A) Glycoprotein-microarray technology showing the spotted tumor glycoprotein (TGP) recognized by the lectin probe $(\mathrm{L})$ and visualized by a fluorescent-labeled anti-lectin antibody (FLAB). (B) Lectin-microarray technology showing the spotted lectin (L) recognized by the tumor glycoprotein probe (TGP) and visualized by a fluorescent-labeled anti-glycoprotein antibody (FLAB) (adapted from [114]).

These technologies also apply to the detection of serum cancer biomarkers and have been used widely for the serum glycoprotein profiling for colorectal cancer [117,118], pancreatic cancer [119], and also for breast cancer using the related approach of multilectin affinity chromatography coupled to HPLC-tandem mass spectrometry [120]. A lectin/glyco-antibody microarray performed on sera from 22 pancreatic cancer sera, discriminated cancer patients from other diseases (35 chronic pancreatitis, 37 diabetes) and normal controls ( 89 controls), by a 70\% increase inthe response of serum 
$\alpha 1 \beta$-glycoprotein to SNA (Sambucus nigra agglutinin) [121]. Using a 45-immobilized lectin microarray, the cell surface glycan changes occurring during the malignant transformation of endometrium, were investigated [122]. Depending on the glycan profile for six lectins including the T/Tn-specific lectins SNA (Sambucus nigra), ACA (Amaranthus caudatus) and BPL (Bauhinia purpurea), the different stages identified in the malignant transformation could be distinguished. Interestingly, cell lines exhibiting the higher anticancer drug-resistance displayed the stronger binding to three lectins (ACA, BPL and the Dolichos biflorus lectin DBL), whereas drug-sensitive cell lines had almost no activity for the lectins. Accordingly, glycan profiling with an adapted lectin-microarray should allow the lectin-microarray technology to predict the success of chemotherapy with selected anticancer drugs. Using a panel of 37 lectins immobilized on a lectin microarray, the normalized fluorescence intensity measured with T/Tn-specific lectins (jacalin, MPL from Maclura pomifera, DBA from Dolichos biflorus, ACA from Amaranthus caudatus and VVA from Vicia villosa) measured for Cy3-labeled gastric cancer cell glycoproteins was stronger compared to the fluorescent intensity measured for Cy3-labeled gastric ulcer cell glycoproteins [123]. Similar results were obtained upon staining of paraffin-embedded gastric cancer and gastric ulcer tissues with MPL and VVA. Similarly changes in the glycan profile of sialylated MUC1 in cholangiocarcinoma were investigated using a 43-lectin-immobilized microarray [124]. Interaction with immobilized WFA (Wisteria floribunda agglutinin) alone proved to be sufficient to discriminate between cholangiocarcinoma and hepatholithiasis. A lectin-based microarray analysis discriminated between healthy patients and patients with colorectal cancer due to the higher degree a $\alpha 2,6$-sialylation and the higher content in high mannose $N$-glycans in serum $\alpha 2$-macroglobulin [125]. Glycosylation profiling of fibronectin performed with a lectin-microarray, showed that PNA distinguishes between two distinct types of non-small cell lung carcinomas, lung adenocarcinoma and large cell lung carcinoma [126]. In a lectin-microarray analysis including the T/Tn-specific lectins ACA (Amaranthus caudatus), ACG (Agrocybe cylindracea), BPL (Bauhinia purpurea), and SNA (Sambucus nigra), a decreased lectin-binding activity was observed for Tn antigen from formalin-fixed human choriocarcinoma tissues [24]. Using a panel of 17 lectins including $\mathrm{T} / \mathrm{Tn}$-specific lectins (ACA, PNA, SNA, VVL, and WFA) immobilized on a microarray integrated on a microfluidic lab-on-a-chip platform, distinct signature glycoprofiles were established for sera and tissue samples from gastritis and gastric cancer patients [127]. A lectin microarray approach using a number of immobilized T/Tn-specific lectins including jacalin, ABL (Agaricus bisporus), BPL (Bauhinia purpurea), GSA (Griffonia simplicifolia), MPA (Maclura pomifera), SBA (soybean), RCA120 (castor bean), VVA (Vicia villosa) and WFL (Wisteria floribunda), was successfully applied to formaline-fixed tumor samples to identify the metastasis-associated changes in glycosylation profiling of breast cancer cells $[128,129]$. Using a lectin microarray and LC-MS/MS approach, PNA (Arachis hypogaea) interacted with HSR-GBM1 and U373 glioblastoma cell lines and was used to capture and characterize the corresponding PNA-binding glycoproteins [130].

The prognostic value of the lectin histochemistry was investigated in various cancer diseases. Expression of the Tn antigen in different types of breast cancer detected by VVA-B 4 lectin, developed very early, before any differentiation and destructive changes become detectable [131]. The binding of VVA- $B_{4}$ to primary cancer cells was attributed to the Tn-antigen-bearing MUC1 protein in primary breast cancer in relation to lymphatic metastasis [132]. Binding of PNA (peanut agglutinin) to a CD44 variant glycoprotein receptor in HT29 colon cancer cells, correlated with an increased metastatic potential [133]. A positive PNA binding to lung adenocarcinoma cells in both the primary tumor and the nodal lesions, was associated with a significantly higher survival rate of patients [134]. Low binding of BPL, the T/Tn-specific Bauhinia purpurea lectin, was identified as a predictive factor for the recurrence of gastric cancer in gastrectomized patients $(n=60)$, in association to lymph node metastasis [135]. An attenuated VVA (Vicia villosa agglutinin) binding to metastatic lymph node cells was also observed in advanced gastric cancer as compared to the strong recognition of the lectin by primary advanced gastric cancer cells [136]. In addition, the histological type of advanced gastric cancer was strongly associated with the binding of soybean lectin (SBA) and Bauhinia purpurea lectin 
(BPL), except for the p53 mutations which correlate well with the Griffonia simplicifolia lectin II (GSA). Conversely, a lower histochemical binding of AAL, the sialyl T-specific lectin from the mushroom Agrocybe aegerita, has been identified as a significant favorable prognostic factor for the free survival in colorectal cancer [137]. In triple-negative breast cancer, tissue microarray showed that binding of RCA-I, the castor bean (Ricinus communis) lectin, to cancer cells correlated with the TNM grades, suggesting that RCA-I-specific glycoproteins of cell surface play a critical role in metastasis [138]. A strong RCA-I binding was associated with a strong incidence of developing metastases in triple-negative breast cancer patients. A lower binding of ACA, the Amaranthus caudatus lectin, to gastric cancer cells correlated with poorer patient prognosis in integrated lectin-microarray and mass sprectrometry analyses [139]. Higher values of serum Wisteria floribunda agglutinin-positive Mac-2 binding protein (WFA+-M2BP) were associated with the risk for development of hepatocellular carcinoma among patients with chronic hepatitis $C$ after sustained virological response by interferon treatment [140].

\section{Toxic Effects of Tn/T-Specific Lectins on Cancer Cells}

The non-exhaustive Table 2 shows the extreme diversity of cancer cell lines that have been addressed to probe the in vitro toxicity of plant and fungal $\mathrm{T} / \mathrm{Tn}$-specific lectins towards transformed cells.

Depending on the lectins, the toxic effect of T/Tn-lectins on cancer cells results in cell death, primarily via apoptosis induction or more or less severe inhibition of the proliferative capacity of cancer cells, or both $[17,35,141-145]$. Autophagy was also incriminated as a toxic effect of $\mathrm{T} / \mathrm{Tn}$-lectins on cancer cells [146]. In addition, the mechanism(s) underlying the cytotoxicity of T/Tn-specific lectins belonging to the type 2 Ribosome-Inactivation Proteins (RIPs), e.g., ricin, abrin and the mistletoe (Viscum album) lectins, partly differ from that of hololectins by the occurrence of a toxic A-chain acting as a potent protein biosynthesis inhibitor, which inhibits the ribosomal protein biosynthesis by depurinating the adenine base at position 2543 of the rRNA 28S [147]. The inhibition of protein synthesis due to the abrin-A chain, thus appears as the major determinant for the cytotoxicity of type 2 RIPs [148], the abrin-B lectin chain allowing the recognition of abrin by the target cell via a specific interaction with membrane $O$-glycoproteins resulting in the subsequent internalization of the toxic A-chain into the cell. However, recent results comparing the toxic effects of different elderberry (Sambucus nigra) type 2 RIPs (SNA-I, SNA-V, and SNRLP) and non-RIP lectins (SNA-II and SNA-IV), point toward a toxic effect of the B-chain lectin that most probably involves an autophagy induction-pathway, in addition to the toxic effect of A-chain on protein biosynthesis [146].

Following their recognition by the cancer cell membrane receptors, $\mathrm{T} / \mathrm{Tn}$-lectins can regulate a number of signaling pathways responsible for the apoptotic, anti-proliferative and autophagic effects on the cancer cells in vitro and in vivo. Table 3 summarizes some of these pathways used by $\mathrm{T} / \mathrm{Tn}$-lectins to induce apoptotic and autophagic effects, and inhibition of the proliferation on cancer cells.

Recent investigations using proteomic approaches including network construction, hub protein identification, targeted microRNA prediction and microarray analyses, pointed out the occurrence of the extreme diversity of signaling pathways associated to apoptosis and DNA modifications in the lectin-treated cancer cells. The Chinese mistletoe lectin-I CMI induced apoptosis in colorectal cancer cells CLY and HT-29 by down-regulating miR-135a\&b expression and up-regulating expression of their APC (Adenomatous Polyposis Coli) target gene [149]. Nine autophagic hub proteins and 13 tumor suppressive miRNA were identified in plant lectin-treated breast carcinoma MCF-7 cells [150]. Using mRNA- and miRNA-microarrays, the SRL (T/Tn-specific Sclerotum rolfsii lectin) treatment of HT29 colon cancer cells resulted in the altered expression of several hundred proteins including MAPK, c-JUN, apoptosis-associated and DNA replication-associated signaling molecules [151]. More recently, up to 22 apoptotic hub proteins were identified in the global human protein-protein interaction network built up for lectin-treated mesothelioma cells according to their different microarray expression, together with the miRNA predicted to negatively regulate these hub proteins [152]. 
Table 2. In vitro cytotoxicity and inhibition of proliferation of cancer cell lines by T/Tn-specific lectins (ABL: Agaricus bisporus lectin; AAL: Agrocybe aegerita lectin; BfL: Bauhinia forficata lectin; GSA-IA4: Griffonia simplicifolia lectin; jacalin (Artocarpus integrifolia lectin); McL: Myrsine coriacea lectin; MCL: Momordica charantia lectin; ML-I, ML-II, ML-III: Mistletoe (Viscum album) lectins; PNA: peanut (Arachis hypogaea) agglutinin; ricin: Ricinus communis lectin; SBA: soybean (Glycine max) agglutinin; SRL: Sclerotium rolfsii lectin; riproximin (Ximenia americana).

\begin{tabular}{|c|c|c|c|c|}
\hline Cancer Cell Line (H: Human, M: Mouse, R: Rat, Hamster: h) & Lectin & Toxicity & Proliferation Inhibition & Ref. \\
\hline HT29 colon $(\mathrm{H})$, MCF-7 breast $(\mathrm{H})$ & ABL & - & + & [153] \\
\hline $\begin{array}{l}\text { HeLa }(\mathrm{H}) \text {, SW } 480 \text { lymph node metastasis }(\mathrm{H}) \text {; SGC-7901, BGC-823 } \\
\text { gastric cancer (H); MGC80-3 gastric adeno-carcinoma (H); HL-60 } \\
\text { leukemia (H); S-180 sarcoma (M) }\end{array}$ & AAL & $+(\mathrm{M})$ & + & [35] \\
\hline NCI-60 tumor cell line panel (H), LOX IMVI melanoma $(\mathrm{H})$ & $\mathrm{BfL}$ & - & + & [46] \\
\hline $\begin{array}{l}\text { SK-MEL-28 melanoma }(\mathrm{H}), \text { HT-144 melanoma }(\mathrm{H}), \text { C32 melanoma } \\
(\mathrm{H}), \text { LS174t, SW1116 colon cancer }(\mathrm{H})\end{array}$ & $\mathrm{GSA}_{-} \mathrm{IA}_{4}$ & + & + & {$[54,154]$} \\
\hline $\begin{array}{l}\text { A431 epidermoid carcinoma }(\mathrm{H}) ; \text { HT29 colorectal carcinoma }(\mathrm{H}) \\
\text { JAr choriocarcinoma }(\mathrm{H}) \text {; H3B hepato-carcinoma }(\mathrm{H}) ; \mathrm{B} 16 \\
\text { melanoma }(\mathrm{M})\end{array}$ & Jacalin, PNA & + & + & {$[155,156]$} \\
\hline $\begin{array}{l}\text { EAC Ehrlich ascites carcinoma; A549 lung carcinoma (H); CNE-1 } \\
\text { CNE-2 nasopharyngeal carcinoma }(\mathrm{H})\end{array}$ & MCL & + & + & {$[157-159]$} \\
\hline $\begin{array}{l}\text { BT20, BT549, MCF7, HS578T, HBL100, T47D breast cancer (H) } \\
\text { SK-Hep-1, SK-Hep-3B hepatocarcinoma (H) }\end{array}$ & ML-I, -II, -III & + & & {$[141,160]$} \\
\hline HT-29 colon $(\mathrm{H})$ & McL & + & + & {$[64]$} \\
\hline $\begin{array}{l}\text { G-361 melanoma }(\mathrm{H}) \text {; HepG2 hepatoma }(\mathrm{H}) \text {; SKGIIIa cervical } \\
\text { carcinoma }(\mathrm{H})\end{array}$ & Ricin & + & + & {$[161,162]$} \\
\hline $\begin{array}{l}\text { Raji, Daudi lymphoma cell lines }(\mathrm{H}) \text {; JAr choriocarcinoma }(\mathrm{H}) \text {; } \\
\text { H3B hepato-carcinoma }(\mathrm{H}) \text {; B16 melanoma }(\mathrm{M})\end{array}$ & SBA & + & - & {$[155,163]$} \\
\hline HT-29 colon $(\mathrm{H})$ & SRL & + & + & [164] \\
\hline $\begin{array}{l}\text { MCF7, MDA-MB231 breast carcinoma (H); U87-MG brain tumor }(\mathrm{H}) \\
\text { HEp2 larynx (H); NCI-H460 lung }(\mathrm{H}) ; \mathrm{HT} 29 \text { colon }(\mathrm{H}) ; \mathrm{PC} 3 \\
\text { prostate }(\mathrm{H}) ; \text { SKW3, K562, BV173 leukemia }(\mathrm{H})\end{array}$ & Riproximin & + & - & {$[85]$} \\
\hline
\end{tabular}


Table 3. Mechanisms involved in the cytotoxic effects of lectins on cancer cells.

\begin{tabular}{|c|c|c|}
\hline Lectin & Mechanism & Ref. \\
\hline (Abrus precatorius) Abrin & $\begin{array}{l}\text { Abrin (type II RIP) induced the caspase 3-dependent but caspase 8-independent apoptotic pathway, mitochondrial membrane } \\
\text { potential damage and production of ROS in Jurkat cells. }\end{array}$ & [165] \\
\hline (Abrus precatorius) A. p. lectin & $\begin{array}{l}\text { Peptides from A. p. lectin induced drastic loss of mitochondrial membrane potential and increase in ROS, leading to symptoms } \\
\text { of early apoptosis through a deregulation of Akt and activation of both JNK, MAPK, p53 and autophagy in HeLa cells. }\end{array}$ & [166] \\
\hline (Abrus precatorius) Abrin P2 & $\begin{array}{l}\text { Abrin P2 suppressed the proliferation of colon HCT-8 cell line and provoked a cell cycle arrest at the S and G2/M phases. Abrin } \\
\text { P2 inhibited cell proliferation via the down-regulation of cyclin B1 and the nuclear antigen Ki67, and the up-regulation of P21. } \\
\text { The abrin P2-induced apoptosis was dose- and time-dependent. }\end{array}$ & [167] \\
\hline (Abrus precatorius) agglutinin AGG & $\begin{array}{l}\text { AGG administered to human breast xenografted athymic nude mice mediated anti-tumorigenic effects through induction of } \\
\text { extrinsic apoptosis via Akt-dependent ROS generation, and inhibition of angiogenesis via inhibition of expression of the } \\
\text { pro-angiogenic factor IGFBP2 in an AKT-dependent manner. }\end{array}$ & [168] \\
\hline (Agrocybe aegerita) lectin AAL & $\begin{array}{l}\text { AAL inhibited the growth of different tumor cell lines HeLa, SW480, SGC-7901, MGC80-3, BGC-823 and HL-60 and induced } \\
\text { apoptosis in HeLa cells. It also displayed DNAse activity. }\end{array}$ & [35] \\
\hline (Arachis hypogaea) peanut agglutinin PNA & PNA induced autophagy and apoptotic cell death in HeLa cells, associated to a concomitant increase in ROS. & [169] \\
\hline (Artocarpus integrifolia) jacalin & $\begin{array}{l}\text { Rounding of A431 (epidermoid carcinoma) and HT29 (colorectal carcinoma) cells due to the stress-induced phosphorylation of } \\
\text { caveolin-1 and p38 and down-regulation of EGFr. }\end{array}$ & [155] \\
\hline (Bauhinia forficata) lectin BfL & $\begin{array}{l}\text { BfL inhibited the adhesion of breast cancer MCF7 cells on laminin, collagen I and fibronectin, decreased the } \alpha 1, \alpha 6 \text { and } \beta 1 \\
\text { integrin subunit expression and increased the } \alpha 5 \text { subunit expression. BfL caused necrosis of MCF7 cells with caspase- } 9 \\
\text { inhibition, DNA fragmentation and cell cycle arrest in the G2/M phase. }\end{array}$ & {$[170]$} \\
\hline (Glycine max) soybean agglutinin SBL & $\begin{array}{l}\text { SBL-mediated autophagy, apoptosis and DNA damage in HeLa cells depend on the generation of ROS. Pre-treatment of HeLa } \\
\text { cells by the ROS scavenger N-acetylcysteine reduced both SBL-induced autophagy, apoptosis and DNA damage. }\end{array}$ & [171] \\
\hline (Momordica charantia) lectin MCL & $\begin{array}{l}\text { MCL induced apoptosis, DNA fragmentation, G1 phase arrest and mitochondrial injury in nasopharyngeal carcinoma NPC cells } \\
\text { in vitro and in vivo, associated with regulation of p38 MAPK, NK and ERK phosphorylation and NO production. MCL } \\
\text { increased cytochrome c release in the cytosol, activated caspase- }-3,-8 \text { and }-9 \text { and enhanced production of PARP. }\end{array}$ & [157] \\
\hline (Momordica charantia) lectin MCL & $\begin{array}{l}\text { MCL treatment induced G2/M phase arrest, autophagy, DNA fragmentation, mitochondrial injury and apoptosis in HCC cells. } \\
\text { Activation of caspase and MAPK pathway was involved in the MCL-induced apoptosis. Up-regulation of truncated Bid (tBid) } \\
\text { was shown to occur during the MCL treatment. }\end{array}$ & {$[172]$} \\
\hline (Momordica charantia) RIP MAP30 & $\begin{array}{l}\text { MAP30 from Momordica charantia promotes apoptosis in both Hep G2 cells (hepatocellular carcinoma) and Hep G2-bearing mice. } \\
\text { The contribution of both caspase-8 regulated extrinsic and caspase-9 intrinsic caspase cascades was evidenced. }\end{array}$ & [173] \\
\hline $\begin{array}{l}\text { (Momordica charantia) } \alpha \text {-momorcharin and } \\
\text { MAP30 }\end{array}$ & $\begin{array}{l}\text { Both RIPs induced cell cycle arrest in S-phase, DNA fragmentation and apoptosis in A549 lung carcinoma cells. Inhibition of cell } \\
\text { proliferation was dose- and time-dependent. }\end{array}$ & {$[158]$} \\
\hline (Sambucus nigra) agglutinin SNA & $\begin{array}{l}\text { SNA activates the signaling pathways of AKT and ERK1/2 in ovarian carcinoma cells. The mitochondrial outer membrane } \\
\text { permeabilization resulted in ROS generation and cytochrome c release in the cytosol. The perturbed mitochondrial respiration } \\
\text { resulted in the G2/M phase cell cycle arrest. }\end{array}$ & [174] \\
\hline (Sclerotium rolfsii) lectin SRL & $\begin{array}{l}\text { SRL caused dose-dependent inhibition of proliferation of MCF-7 and ZR-75 breast cancer cells via induction of cellular } \\
\text { apoptosis. Inhibitors of caspase- } 3,-8 \text { and }-9 \text { prevented the apoptosis to occur. }\end{array}$ & {$[164]$} \\
\hline
\end{tabular}


Table 3. Cont.

\begin{tabular}{|c|c|c|}
\hline Lectin & Mechanism & Ref. \\
\hline (Viscum album) Korean mistletoe lectin VCA & $\begin{array}{l}\text { VCA elicited apoptosis in SK-Hep-1 p53-positive and Hep 3B p53-negative hepatocarcinoma cell lines by down-regulation of } \\
\text { Bcl-2 and up-regulation of Bax functioning upstream of caspase-3. Down-regulation of telomerase activity occurred in both } \\
\text { VCA-treated cells. }\end{array}$ & [141] \\
\hline (Viscum album) Mistletoe lectin-1 ML-1 & $\begin{array}{l}\text { CM-1 induced apoptosis in colorectal cancer cells by down-regulating the miR-135a\&b miRNAs expression. The expression of } \\
\beta \text {-catenin was up-regulated. }\end{array}$ & [149] \\
\hline (Viscum album) Recombinant aviscumine & $\begin{array}{l}\text { The mechanism of aviscumin-mediated cell death on multiple cell types was solely induced by the toxic A-chain. The } \\
\text { mechanism is independent from the death receptor Fas and independent of the activity of the anti-apoptotic transcription factor } \\
\text { NFKB. Treatment with aviscumine inhibited growth in various metastases mouse models including C } 8 \text { colon carcinoma, Lewis } \\
\text { lung sarcoma, Renca renal sarcoma, etc. }\end{array}$ & [175] \\
\hline (Viscum album) Korean mistletoe lectin VCA & $\begin{array}{l}\text { Treatment of B16BL6 and B16F10 melanoma cells with VCA resulted in G0/G1 phase arrest and induced an increase in both } \\
\text { early and late apoptosis. Both VCA and mistletoe extracts increased activated multiple caspases (caspase-1,3, 4, 5, 6, 7, } 8 \text { and 9) } \\
\text { and a decrease of procaspase } 3 \text { and } 8 .\end{array}$ & [176] \\
\hline $\begin{array}{l}\text { (Ricinus communis) agglutinin RCA and ricin } \\
\text { A-chain }\end{array}$ & $\begin{array}{l}\text { Treatment of cancer cells in vitro by ricin and ricin A-chain activates caspase } 3 \text { and caspase } 8 \text {, but not caspase 9. In vivo, cell } \\
\text { death depends on the necrotic effect of the RIP. }\end{array}$ & [177] \\
\hline (Ricinus communis) ricin & Ricin inhibited the proliferation of HeLa cells by inducing apoptosis, chromatin condensation and nuclear fragmentation. & [178] \\
\hline (Ricinus communis) ricin and riproximin & $\begin{array}{l}\text { Unfolding protein response UPR to endoplasmic reticulum stress was induced in both HCT116 and MDA-MB-231 cells. } \\
\text { Apoptosis was induced by concentrations of RIPs-II at which the UPR-related genes are still translated. }\end{array}$ & [179] \\
\hline (Viscum album) Korean mistletoe lectin-II & Lectin-II induced the activation of caspase- $3,-8$ and -9 of myeloleukemic U937 cells in a time- and dose-dependent manner. & [180] \\
\hline (Viscum album) mistletoe lectin-II & $\begin{array}{l}\text { Apoptotic cell death of U937 cells was induced by the generation of pro-oxidants mediating the JNK/SAPK activation, } \\
\text { cytochrome c release, activation of caspase-9- and -3-like proteases, and PARP cleavage. }\end{array}$ & [181] \\
\hline (Viscum album) Korean mistletoe lectin VCA & $\begin{array}{l}\text { Induction of apoptosis in A253 cells through activation of caspase-3 and inhibition of telomerase activity through transcriptional } \\
\text { down-regulation of hTERT. Inhibition of telomerase activity resulted from dephosphorylation of Akt. }\end{array}$ & [182] \\
\hline $\begin{array}{l}\text { (Viscum album) European mistletoe } \\
\text { lectin-containing extracts }\end{array}$ & $\begin{array}{l}\text { In vitro and ex vivo treatment of Ewing sarcoma cells by mistletoe extracts inhibited proliferation and induced a dose-dependent } \\
\text { apoptosis via intrinsic and extrinsic apoptotic pathways, as evidenced by activation of both caspase- } 8 \text { and caspase- } 9 \text {. }\end{array}$ & [183] \\
\hline $\begin{array}{l}\text { (Viscum album) European mistletoe } \\
\text { lectin-containing extracts }\end{array}$ & $\begin{array}{l}\text { Treatment of Ewing sarcoma cells by mistletoe extracts impacted both gene and protein expression. Cell response to oxidative } \\
\text { stress induced the activation of the MAPK signaling pathway. }\end{array}$ & [184] \\
\hline (Ximenia americana) riproximin & $\begin{array}{l}\text { Riproximin induced cytotoxic effects on breast cancer cell lines MDA-MB-231 and MCF-7. Riproximin treatment caused arrest in } \\
\text { S phase and nuclear fragmentation of the cell, induced cytokine IL24/MDA-7 and ER-stress-related GADD genes. An inhibition } \\
\text { of the genes involved in migration of colony was observed. }\end{array}$ & [185] \\
\hline
\end{tabular}


Despite the cytotoxic effects on both healthy and malignant cells, some T/Tn-specific lectins display a pronounced mitogenic effect susceptible to improve the proliferation of cancer cells. At low concentrations, peanut lectin stimulates the proliferation of colon cancer cell lines (HT29, T84, Caco2) due to the activation of the hepatocyte growth factor c-Met and the resulting activation of MAPK [27]. The tumor growth of BALB/c mice fed with daily doses of Agaricus bisporus lectin ABL, was significantly enhanced as compared with control mice, suggesting an immunomodulatory effect of the lectin that reduces the innate and adaptive responses of the cells [186]. Upon fixation at the cell surface, $\mathrm{T} / \mathrm{Tn}$-specific lectins can activate signaling pathways responsible for the production of cytokines susceptible to induce an immune response against tumor cells. Mistletoe (Viscum album) lectin ML-I induces the production by human PBMCs (Peripheral Blood Mononuclear Cells) of a set of IL-6, IL-10, IL-12 and TNF $\alpha$ [187-189]. The Korean mistletoe lectin also induces the secretion of IL-12 by human dendritic cells [190]. However, the immunomodulatory effects of plant and fungal lectins do not rely on the T/Tn-binding specificity since many other lectins with different carbohydrate-binding specificies, for example legume lectins such as PHA-L (Phaseolus vulgaris) [191] or ArtiM from Artocarpus heterophyllus [192], also display immunomodulatory properties.

\section{Tn/T-Specific Lectins as Targeting Aids for the Photodynamic Treatment of Tumors}

The local treatment of tumors using photodynamic therapy (PDT), uses photosensitizers which, upon illumination at a specific wavelength, become activated and produce different forms of active singlet oxygen known as ROS (Reactive Oxygen Species) that kill the tumor cells (Figure 7). Following its injection in the bloodstream or directly into the tumor, the photosensitizer is equally absorbed by healthy and tumor cells but it disappears faster from healthy cells, compared to tumor cells. Accordingly, the laser lightening of the tumor is performed 48 to $72 \mathrm{~h}$ after the injection of the photosensitizer, to ensure that cancer cells will be killed without harming the neighboring healthy cells.

Although most of the photosensitizing molecules used for PDT stay longer in cancer cells compared to healthy cells, their combination with other molecules that specifically recognize the receptors located at the cell surface, greatly enhances the targeting of photosensitizers to the tumors. Due to the widespread distribution of aberrant $O$-glycans on the surface of most cancer cells, T/Tn-specific lectins have been identified early as potential targeting molecules available for PDT $[193,194]$. The non-covalent binding between porphyrins and different $\mathrm{T} / \mathrm{Tn}$-specific lectins including jacalin from the Jackfruit (Artocarpus integrifolia) [195], the snake gourd (Trichosanthes aguina) [196], and the bitter gourd (Momordica charantia) [197], was investigated. The binding of lectins to porphyrin and phycobilin molecules was further extended to the T/Tn-specific lectin PNA [198] and to other legume lectins such as the mannose-specific concanavalin A [199] and the garden pea lectin [200]. The interaction of jacalin with phycobilin, another photosensitizing molecule, was also studied [201]. However, all of these complexes resulting from the non covalent interaction of lectins with porphyrins and phycobilins, exhibited a rather weak stability in in vitro experiments performed with cancer cell lines, suggesting that $\mathrm{T} / \mathrm{Tn}$-specific lectins require to be covalently bound to photosensitizing molecules to properly target the cancer cells [202]. In a series of experiments, Poiroux et al. [203-205], showed the relevance of the covalent binding of Morniga $\mathrm{G}$, the $\mathrm{T} / \mathrm{Tn}$-specific lectin from the mulberry (Morus nigra), to porphyrins and phthalocyanines to improve both the stability of the lectin-photosensitizer complexes and their efficacy to kill Jurkat leukemia cells. A more sophisticated conjugation of targeting molecules (antibodies and lectins) to photosensitizers using the drug carriers Zn-porphyrin-cyclodextrins was subsequently introduced by Kejík et al. [206] as a versatile delivery system for anticancer drugs. Recently, another approach based on the conjugation of jacalin to phthalocyanine-PEG gold nanoparticles (4 $\mathrm{nm}$ in diameter), was developed by Obaid et al. [207,208], to selectively target and destroy the HT-29 human colon and the SK-BR-3 human breast adenocarcinoma cells. The conjugates consist of gold nanoparticles covered by a monolayer of Zn phthalocyanine and polyethylene glycol (PEG) further functionalized with jacalin (ca. 6 jacalin molecules bound to each gold nanoparticle) (Figure 8). 


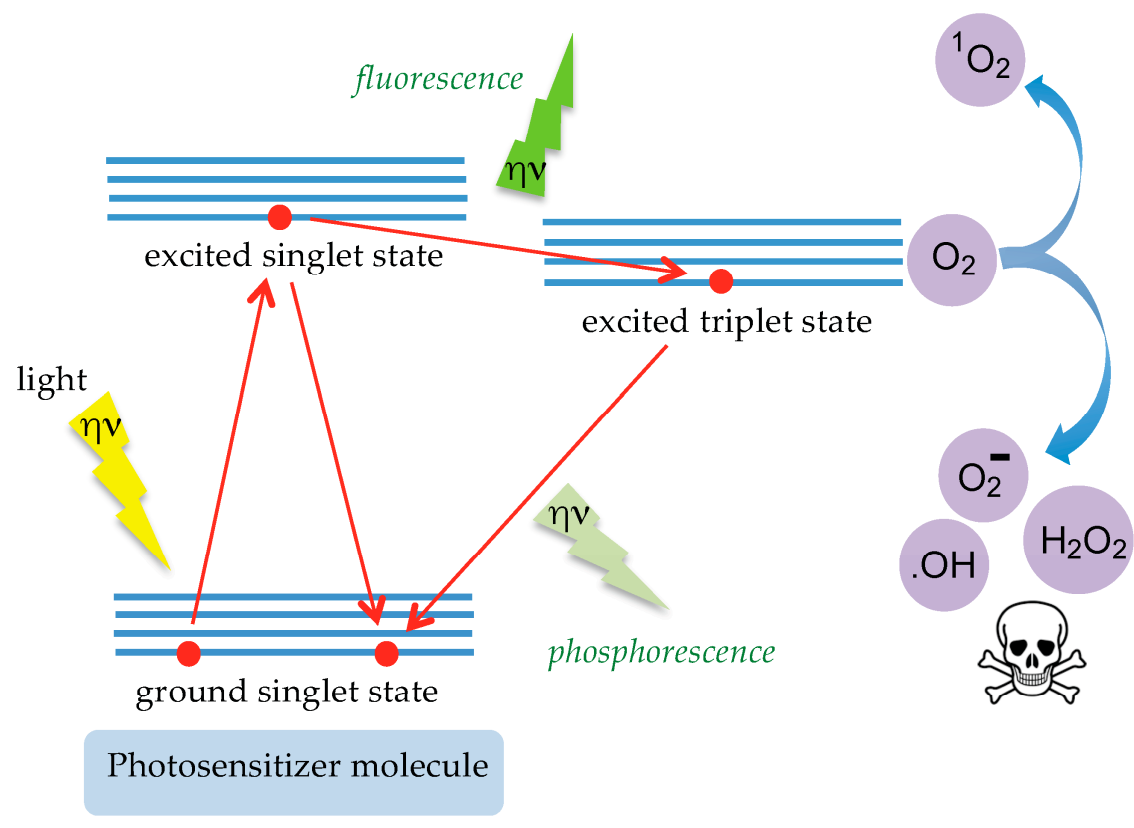

Figure 7. Mechanism of action of photosensitizers. Upon illumination at a selective wavelength (light), the photosensitizer becomes excited (excited singlet state) and reaches, after relaxation, a steady-excited state (excited triplet state) for a longer duration associated with the emission of fluorescence. Collisions with $\mathrm{O}_{2}$ produce different forms of active oxygen $\left(\mathrm{O}_{2}{ }^{-}, \mathrm{OH}\right.$, and $\left.\mathrm{H}_{2} \mathrm{O}_{2}\right)$ able to kill the cancer cells.

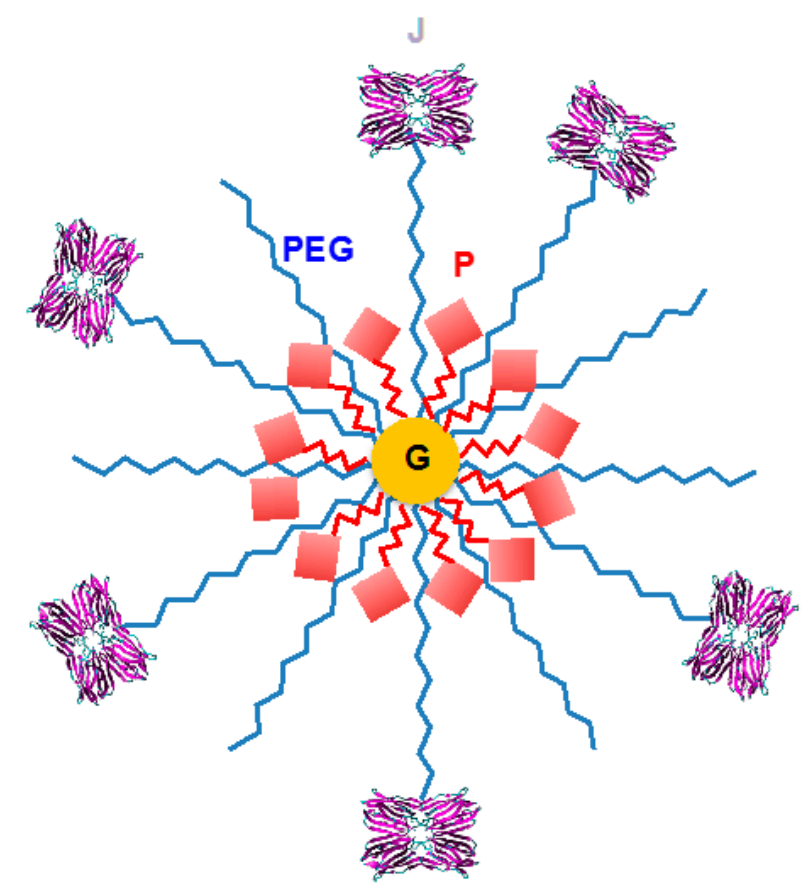

Figure 8. Lectin conjugated phthalocyanine-PEG gold nanoparticle made of a gold nanoparticle (G) covered with Zn phthalocyanine molecules (P) and polyethylene glycol (PEG) covalently linked to jacalin molecules (J) (adapted from [207]).

The advantage is that this conjugation technique enables a higher concentration of photosensitizers at the surface of the tumor cells, susceptible to improve the efficiency of PDT. Once anchored to the cell surface by the lectin moiety, the conjugates are further endocytosed into the cells and produce singlet oxygen forms upon illumination at the wavelength corresponding to the activation of $\mathrm{Zn}$ 
phthalocyanin. The possible use of lectin-coated nanoparticles to specifically target tumors and their microvascular environment has recently been argued as new anticancer therapeutic opportunities [209]. Obviously, the ability of plant and fungal lectins to be endocytosed quickly following the specific recognition of glycans at the cancer cell surface, make them good candidates to build photosensitizer conjugates adapted to PDT. In this respect, FITC-labeled Morniga G, the T/Tn-specific lectin from black elderberry Morus nigra, was shown to readily enter Jurkat cells within 5 min of incubation at $37^{\circ} \mathrm{C}$, upon fixation at the cell surface [210]. Recently, another approach based on the conjugation of galactodendrimers to phthalocyanine was proposed by Pereira et al. [211], to specifically target the carbohydrate-binding receptors occurring on the tumor cells, instead of the aberrant $O$-glycans exposed at the tumor cell surface.

To date, PDT is restricted to the treatment of superficial skin tumors and tumors located in the body cavities such as esophageal cancer or non-small cell lung cancer [212]. However, the progress achieved in the photosensitizer efficacy and specificity towards cancer cells should expand the use of PDT to other cancers, e.g., cancers of the peritoneal cavity, brain and prostate. The improvement of the laser source equipment that delivers the activating light to the photosensitizing molecules absorbed by the tumor is also of paramount importance in order to apply PDT to the treatment of deeper and larger tumors $[213,214]$. In this respect, the use of new photosensitizer molecules activatable upon illumination at red and infrared wavelengths greatly enhances the efficacy of the PDT due to a deeper penetration of more efficient red and infrared wavelengths into the malignant cells.

\section{Conclusions}

Plant and fungal lectins displaying a T/Tn-specificity have been widely used as relevant probes for the histochemical detection of aberrant $O$-glycan glycomarkers expressed at the surface of malignant cells. With the aid of the fast-developing glycan- and lectin-microarray technologies, our increasing knowledge on the fine carbohydrate-binding specificity of plant and fungal lectins has revealed the extreme versatility of the lectin tool to specifically recognize discrete/subtle differences in the expression of altered glycans by cancer cells. Depending on the lectins, the affinity towards complex $\mathrm{O}$-glycans and their chemical substitutions such as sialylation or sulfation can vary in a large proportion. The ability of $\mathrm{T} / \mathrm{Tn}$-specific lectins to accommodate large $\mathrm{O}$-glycans to the extended carbohydrate-binding site via a complex network of hydrogen bonds and hydrophobic interactions, accounts for such versatility. Variations in the shape and size of the extended carbohydrate-binding site from one lectin to another, readily explain the discrepancies observed in the binding activity among different $\mathrm{T} / \mathrm{Tn}$-specific lectins. Compared to monoclonal antibodies used as standard probes for the detection of the $O$-glycosylation aberrations occurring at the cancer cell surface, plant and fungal $\mathrm{T} / \mathrm{Tn}$-specific lectins consist of a complementary sugar-recognition domain that is equally performant, if not more, in the recognition of complex $O$-glycans. Their flexibility in the recognition of complex $\mathrm{O}$-glycans, make $\mathrm{T} / \mathrm{Tn}$-specific lectins good candidates available for the specific targeting of aberrant $\mathrm{O}$-glycans in the photodynamic treatment of cancer. In vitro experiments performed with Morniga-G, the T/Tn-specific lectin of elderberry (Morus nigra), demonstrated the feasibility to covalently attach a plant lectin to photosensitizers, the subsequent specific recognition and engulfment by transformed cells, and the selective killing of the sole transformed cells [203-205]. These stimulating results pave the way for the use of carefully selected T/Tn-specific lectins as targeting molecules for the photodynamic treatment of cancers.

Author Contributions: Guillaume Poiroux, Annick Barre and Hervé Benoist provided the bibliographic informations and analyses. Pierre Rougé provided the molecular docking pictures. Els J. M. van Damme and Pierre Rougé participated in the writing of the review.

Conflicts of Interest: The authors declare no conflict of interest. 


\section{References}

1. Hakomori, S. Aberrant glycosylation in tumors and tumor-associated carbohydrate antigens. Adv. Cancer Res. 1989, 52, 257-331. [PubMed]

2. Cazet, A.; Julien, S.; Bobowski, M.; Burchell, J.; Delannoy, P. Tumor-associated carbohydrate antigens in breast cancer. Breast Cancer Res. 2010, 12, 204. [CrossRef] [PubMed]

3. Stowell, S.R.; Ju, T.; Cummings, R.D. Protein glycosylation in cancer. Annu. Rev. Pathol. 2015, 10, 473-510. [CrossRef] [PubMed]

4. Springer, G.F.; Desai, P.R. Tn epitopes, immunoreactive with ordinary anti-Tn antibodies, on normal, desialylated human erythrocytes and on Thomsen-Friedenreich antigen isolated therefrom. Mol. Immunol. 1985, 22, 1303-1310. [CrossRef]

5. Itzkowitz, S.; Bloom, E.; Lau, T.; Kim, Y. Mucin associated Tn and sialosyl-Tn antigen expression in colorectal polyps. Gut 1992, 33, 518-523. [CrossRef] [PubMed]

6. Springer, G.F.; Desai, P.R.; Ghazizadeh, M.; Tegtmeyer, H. T/Tn pancarcinoma autoantigens: Fundamental, diagnostic, and prognostic aspects. Cancer Detect. Prev. 1995, 19, 173-182. [PubMed]

7. Terasawa, K.; Furumoto, H.; Kamada, M.; Aono, T. Expression of Tn and sialyl-Tn antigens in the neoplastic transformation of uterine cervical epithelial cells. Cancer Res. 1996, 56, 2229-2232. [PubMed]

8. Cao, Y.; Stosiek, P.; Springer, G.F.; Karsten, U. Thomsen-Friedenreich-related carbohydrate antigens in normal adult human tissue: A systematic and comparative study. Histochem. Cell Biol. 1996, 106, 197-207. [CrossRef] [PubMed]

9. Hanisch, F.G.; Baldusn, S.E. The Thomsen-Friedenreich (TF) antigen: A critical review on the structural, biosynthetic and histochemical aspects of a pancarcinoma-associated antigen. Histol. Histopathol. 1997, 12, 263-281. [PubMed]

10. Cao, Y.; Merling, A.; Karsten, U.; Goletz, S.; Punzel, M.; Kraft, R.; Butschak, G.; Schwartz-Albiez, R. Expression of CD175 (Tn), CD175s (sialosyl-Tn) and CD176 (Thomsen-Friedenreich antigen) on malignant human hematopoietic cells. Int. J. Cancer 2008, 123, 89-99. [CrossRef] [PubMed]

11. Lin, W.M.; Karsten, U.; Goletz, S.; Cheng, R.C.; Cao, Y. Co-expression of CD173 (H2) and CD174 (Lewis Y) with CD44 suggests that fucosylated histo-blood group antigens are markers of breast cancer-initiating cells. Virchows Arch. 2010, 456, 403-409. [CrossRef] [PubMed]

12. Lin, W.M.; Karsten, U.; Goletz, S.; Cheng, R.C.; Cao, Y. Expression of CD176 (Thomsen-Friedenreich antigen) on lung, breast and liver cancer-initiating cells. Int. J. Exp. Pathol. 2011, 92, 97-105. [CrossRef] [PubMed]

13. Rhodes, J.M. Usefulness of novel tumour markers. Ann. Oncol. 1999, 10, 118-121. [CrossRef] [PubMed]

14. Van Elssen, C.H.; Frings, P.W.; Bot, F.J.; van de Vijver, K.K.; Huls, M.B.; Meek, B.; Hupperets, P.; Germeraad, W.T.; Bos, G.M. Expression of aberrantly glycosylated mucin-1 in ovarian cancer. Histopathology 2010, 57, 597-606. [CrossRef] [PubMed]

15. Fuster, M.M.; Esko, J.D. The sweet and sour of cancer: Glycans as novel therapeutic targets. Nat. Rev. Cancer 2005, 5, 526-542. [CrossRef] [PubMed]

16. Gemeiner, P.; Mislovicová, D.; Tkác, J.; Svitel, J.; Pätoprstý, V.; Hrabárová, E.; Kogan, G.; Kozár, T. Lectinomics II. A highway to biomedical/clinical diagnostics. Biotechnol. Adv. 2009, 27, 1-15. [CrossRef] [PubMed]

17. Glavey, S.V.; Huynh, D.; Reagan, M.R.; Manier, S.; Moschetta, M.; Kawano, Y.; Roccaro, A.M.; Ghobrial, I.M.; Joshi, L.; O'Dwyer, M.E. The cancer glycome: Carbohydrates as mediators of metastasis. Blood Rev. 2015, 29, 269-279. [CrossRef] [PubMed]

18. Feizi, T. Demonstration by monoclonal antibodies that carbohydrate structures of glycoproteins and glycolipids are onco-developmental antigens. Nature 1985, 314, 53-57. [CrossRef] [PubMed]

19. Roxby, D.J.; Morley, A.A.; Burpee, M. Detection of the Tn antigen in leukemia using monoclonal anti-Tn antibody and Immunohistochemistry. Br. J. Haematol. 1987, 67, 153-156. [CrossRef] [PubMed]

20. Springer, G.F.; Chendrasekaran, E.V.; Desai, P.R.; Tegtmeyer, H. Blood Tn-active macromolecules from human carcinomas and erythrocytes: Characterization of and specific reactivity with mono- and poly-clonal anti-Tn antibodies induced by various immunogens. Carbohydr. Res. 1988, 178, 271-292. [CrossRef]

21. Kjeldsen, T.; Clausen, H.; Hirohashi, S.; Ogawa, T.; Iijima, H.; Hakomori, S. Preparation and characterization of monoclonal antibodies directed to the tumor-associated $O$-linked sialosyl-2 $\rightarrow 6 \alpha-N$-acetylgalactosaminyl (sialosyl-Tn) epitope. Cancer Res. 1988, 48, 2214-2220. [PubMed] 
22. Siddiki, B.; Ho, J.J.; Huang, J.; Byrd, J.C.; Lau, E.; Yuan, M.; Kim, Y.S. Monoclonal antibody directed against colon cancer mucin has high specificity for malignancy. Int. J. Cancer 1993, 54, 467-474. [CrossRef] [PubMed]

23. Rougé, P.; Peumans, W.J.; van Damme, E.J.M.; Barre, A.; Singh, T.; Wu, J.H.; Wu, A.M. Glycotope structures and intramolecular affinity factors of plant lectins for Tn/T antigens. Adv. Exp. Med. Biol. 2011, 705, 143-154. [PubMed]

24. Kobayashi, Y.; Masuda, K.; Banno, K.; Kobayashi, N.; Umene, K.; Nogami, Y.; Tsuji, K.; Ueki, A.; Nomura, H.; Sato, K.; et al. Glycan profiling of gestational choriocarcinoma using a lectin microarray. Oncol. Rep. 2014, 31, 1121-1126. [CrossRef] [PubMed]

25. Singh, R.; Bandyopadhyay, D. MUC1: A target molecule for cancer therapy. Cancer Biol. Ther. 2007, 6, 481-486. [CrossRef] [PubMed]

26. Wu, A.M.; Singh, T.; Liu, J.H.; André, S.; Lensch, M.; Siebert, H.C.; Krzeminski, M.; Bonvin, A.M.J.J.; Kaltner, H.; Wu, J.H.; et al. Adhesion/growth-relgulatory galectins: Insights into their ligand selectivity using natural glycoproteins and glycotopes. Adv. Exp. Med. Biol. 2011, 705, 117-141. [PubMed]

27. Singh, R.; Subramanian, S.; Rhodes, J.M.; Campbell, B.J. Peanut lectin stimulates proliferation of colon cancer cells by interaction with glycosylated CD44v6 isoforms and consequential activation of c-Met and MAPK: Functional implications for disease-associated glycosylation changes. Glycobiology 2006, 16, 594-601. [CrossRef] [PubMed]

28. Peumans, W.J.; Hao, Q.; van Damme, E.J.M. Ribosome-inactivating proteins from plants: More than RNA $N$-glycosidases? FASEB J. 2001, 15, 1493-1506. [CrossRef] [PubMed]

29. Kumar, G.S.; Appukuttan, P.S.; Basu, D. $\alpha$-D-Galactose-specific lectin from jack fruit (Artocarpus integra) seed. J. Biosci. 1982, 4, 257-261. [CrossRef]

30. Ahmed, H.; Chatterjee, B.P. Further characterization and immunochemical studies on the carbohydrate specificity of jackfruit (Artocarpus integrifolia) lectin. J. Biol. Chem. 1989, 264, 9365-9372. [PubMed]

31. Jeyaprakash, A.A.; Katiyar, S.; Swaminathan, C.P.; Sekar, K.; Surolia, A.; Vijayan, M. Structural basis of the carbohydrate specificitiesof jacalin: An X-ray and modeling study. J. Mol. Biol. 2003, 332, 217-228. [CrossRef]

32. Wu, A.M.; Shen, F.; Herp, A.; Wu, J.H. Interaction of hamster submaxillary sialyl-Tn and Tn glycoproteins with Gal, GalNAc and GlcNAc specific lectins. Mol. Immunol. 1994, 31, 485-490. [CrossRef]

33. Irazoqui, F.J.; Vides, M.A.; Nores, G.A. Structural requirements of carbohydrates to bind Agaricus bisporus lectin. Glycobiology 1999, 9, 59-64. [CrossRef] [PubMed]

34. Carrizo, M.E.; Capaldi, S.; Perduca, M.; Irazoqui, F.J.; Nores, G.A.; Monaco, H.L. The antineoplastic lectin of the common edible mushroom (Agaricus bisporus) has two binding sites, each specific for a different configuration at a single epimeric hydroxyl. J. Biol. Chem. 2005, 280, 10614-10623. [CrossRef] [PubMed]

35. Zhao, C.; Sun, H.; Tong, X.; Qi, Y. An antitumour lectin from edible mushroom Agrocybe aegerita. Biochem. J. 2003, 374, 321-327. [CrossRef] [PubMed]

36. Cammue, B.; Stinissen, H.M.; Peumans, W.J. A new type of cereal lectin from leaves of couch grass (Agropyrum repens). Eur. J. Biochem. 1985, 148, 315-322. [CrossRef] [PubMed]

37. Transue, T.R.; Smith, A.K.; Mo, H.; Goldstein, I.J.; Saper, M.A. Structure of benzyl T-antigen disaccharide bound to Amaranthus caudatus agglutinin. Nat. Struct. Biol. 1997, 4, 779-783. [CrossRef] [PubMed]

38. Wu, A.M.; Wu, J.H.; Yang, Z.; Singh, T.; Goldstein, I.J.; Sharon, N. Differential contributions of recognition factors of two plant lectins, Amaranthus caudatus lectin and Arachis hypogaea agglutinin, reacting with Thomsen-Friedenreich disaccharide (Gal $\beta 1-3 G a l N A c \alpha 1-S e r / T h r)$. Biochimie 2008, 90, 1769-1780. [CrossRef] [PubMed]

39. Zenteno, E.; Lascurain, R.; Montaño, L.F.; Vazquez, L.; Debray, H.; Montreuil, J. Specificity of Amaranthus leucocarpus lectin. Glycoconj. J. 1992, 9, 204-208. [CrossRef] [PubMed]

40. Lotan, R.; Skutelsky, E.; Danon, D.; Sharon, N. The purification, composition, and specificity of the anti-T lectin from peanut (Arachis hypogaea). J. Biol. Chem. 1975, 250, 8518-8523. [PubMed]

41. Ravishankar, R.; Ravindran, M.; Suguna, K.; Surolia, A.; Vijayan, M. The specificity of peanut agglutinin for Thomsen-Friedenreich antigen is mediated by water-bridges. Curr. Sci. 1997, 72, 855-861.

42. Moreira, R.A.; Castelo-Branco, C.C.; Monteiro, A.C.; Tavares, R.O.; Beltramini, L.M. Isolation and partial characterization of a lectin from Artocarpus incisa L. seeds. Phytochemistry 1998, 47, 1183-1188. [CrossRef]

43. Tachibana, K.; Nakamura, S.; Wang, H.; Iwasaki, H.; Tachibana, K.; Maebara, K.; Cheng, L.; Hirabayashi, J.; Narimatsu, H. Elucidation of binding specificity of jacalin toward O-glycosylated peptides: Quantitative analysis by frontal affinity chromatography. Glycobiology 2006, 16, 46-53. [CrossRef] [PubMed] 
44. Lee, C.S.; Muthusamy, A.; Abdul-Rahman, P.S.; Bhavanandan, V.P.; Hashim, O.H. An improved lectin-based method for the detection of mucin-type O-glycans in biological samples. Analyst 2013, 138, 3522-3529. [CrossRef] [PubMed]

45. Singh, T.; Chatterjee, U.; Wu, J.H.; Chatterjee, B.P.; Wu, A.M. Carbohydrate recognition factors of a T $\alpha$ $($ Gal $\beta 1 \rightarrow 3$ GalNAc $\alpha 1 \rightarrow$ Ser/Thr) and Tn (GalNAc $\alpha 1 \rightarrow$ Ser/Thr) specific lectin isolated from the seeds of Artocarpus lakoocha. Glycobiology 2005, 15, 67-78. [CrossRef] [PubMed]

46. Lubkowski, J.; Durbin, S.V.C.; Silva, M.C.; Farnsworth, D.; Gildersleeve, J.C.; Oliva, M.L.; Wlodawer, A. Structural analysis and unique molecular recognition properties of a Bauhinia forficata lectin that inhibits cancer cell growth. FEBS J. 2017, 284, 429-450. [CrossRef] [PubMed]

47. Wu, A.M.; Wu, J.H.; Liu, J.H.; Singh, T. Recognition profile of Bauhinia purpurea agglutinin (BPA). Life Sci. 2004, 74, 1763-1779. [CrossRef] [PubMed]

48. Wu, A.M.; Wu, J.H.; Chen, Y.Y.; Tsai, M.S.; Herp, A. Forssman pentasaccharide and polyvalent Gal $\beta 1 \rightarrow 4$ GlcNAc as major ligands with affinity for Caragana arborescens agglutinin. FEBS Lett. 1999, 463, 225-230. [CrossRef]

49. Wu, A.M.; Song, S.C.; Chang, S.C.; Wu, J.H.; Chang, K.S.; Kabat, E.A. Further characterization of the binding properties of a GalNAc specific lectin from Codium fragile subspecies tomentosoides. Glycobiology 1997, 7, 1061-1066. [CrossRef] [PubMed]

50. Piller, V.; Piller, F.; Cartron, J.P. Comparison of the carbohydrate-binding specificities of seven $N$-acetyl-D-galactosamine-recognizing lectins. Eur. J. Biochem. 1990, 191, 461-466. [CrossRef] [PubMed]

51. Singh, T.; Wu, J.H.; Peumans, W.J.; Rougé, P.; van Damme, E.J.M.; Alvarez, R.A.; Blixt, O.; Wu, A.M. Carbohydrate specificity of an insecticidal lectin isolated from the leaves of Glechoma hederacea (ground ivy) towards mammalian glycoconjugates. Biochem. J. 2006, 393, 331-341. [CrossRef] [PubMed]

52. Sletmoen, M.; Dam, T.K.; Gerken, T.A.; Stokke, B.T.; Brewer, C.F. Single-molecule pair studies of the interaction of the $\alpha$-GalNAc (Tn-antigen) form of porcine submaxillary mucin with soybean agglutinin. Biopolymers 2009, 91, 719-728. [CrossRef] [PubMed]

53. Wu, A.M.; Wu, J.H.; Song, S.C.; Kabat, E.A. Bandeiraea (Griffonia) simplicifolia lectin I, isolectin $\mathrm{A}_{4}$, reacting with (GalNAc $\alpha 1 \rightarrow$ Ser/Thr) ou galabiose (Gal $\alpha 1 \rightarrow 4 \mathrm{Gal})$ containing ligands. FEBS Lett. 1996, 398, 183-186. [PubMed]

54. Chen, Y.F.; Boland, C.R.; Kraus, E.R.; Goldstein, I.J. The lectin Griffonia simplicifolia I-A 4 (GS I-A 4 ) specifically recognizes terminal $\alpha$-linked $N$-acetylgalactosaminyl groups and is cytotoxic to the human colon cancer cell lines LS174t and SW1116. Int. J. Cancer 1994, 57, 561-567. [CrossRef] [PubMed]

55. Guillot, J.; Giollant, M.; Damez, M.; Dusser, M. Isolation and characterization of a lectin from the mushroom, Lactarius deliciosus. J. Biochem. 1991, 109, 840-845. [CrossRef] [PubMed]

56. Giollant, M.; Guillot, J.; Damez, M.; Dusser, M.; Didier, P.; Didier, E. Characterization of a lectin from Lactarius deterrimus. Research on the possible involvement of the fungal lectin in recognition between mushroom and spruce during the early stages of mycorrhizae formation. Plant Physiol. 1993, 101, 513-522. [CrossRef] [PubMed]

57. Zenteno, R.; Chávez, R.; Portugal, D.; Páez, A.; Lascurain, R.; Zenteno, E. Purification of a $\mathrm{N}$-acetyl-D-galactosamine specific lectin from the orchid Laelia autumnalis. Phytochemistry 1995, 40, 651-655. [CrossRef]

58. Thompson, A.; Zhang, Z.; Ton-that, H.; Biesterfeldt, J.; Ogata, C.; Xu, L.; Johnston, R.A.; Young, N.M. Structure of the complex of Maclura pomifera agglutinin and the T-antigen disaccharide, Gal $\beta 1,3 \mathrm{GalNAc}$. J. Biol. Chem. 1998, 273, 6312-6318.

59. Wu, A.M. Polyvalent GalNAc $\alpha 1 \rightarrow$ Ser $/$ Thr $(\mathrm{Tn})$ and Gal $\beta 1 \rightarrow 3$ GalNAc $\alpha 1 \rightarrow$ Ser $/ \mathrm{Thr}(\mathrm{T} \alpha)$ as the most potent recognition factors involved in Maclura pomifera agglutinin-glycan interactions. J. Biomed. Sci. 2005, 12, 135-152. [CrossRef] [PubMed]

60. Thurnher, M.; Clausen, H.; Sharon, N.; Berger, E.G. Use of O-glycosylation-defective human lymphoid cell lines and flow cytometry to delineate the specificity of Moluccella laevis lectin and monoclonal antibody 5F4

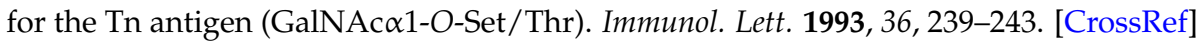

61. Teneberg, S.; Leonardsson, I.; Angström, J.; Ehrlich-Rogozinski, S.; Sharon, N. Characterization of the specificity of binding of Moluccella laevis lectin to glycosphingolipids. Glycoconj. J. 1994, 11, 418-423. [CrossRef] [PubMed] 
62. Chandran, T.; Sharma, A.; Vijayan, M. Structural studies on a non-toxic homologue of type II RIPs from bitter gourd: Molecular basis of non-toxicity, conformational selection and glycan structure. J. Biosci. 2015, 40, 929-941. [CrossRef] [PubMed]

63. Singh, T.; Wu, J.H.; Peumans, W.J.; Rougé, P.; van Damme, E.J.M.; Wu, A.M. Recognition profile of Morus nigra agglutinin (Morniga $G$ ) expressed by monomeric ligands, simple clusters and mammalian polyvalent glycotopes. Mol. Immunol. 2007, 44, 451-462. [CrossRef] [PubMed]

64. Medeiros, A.; Berois, N.; Incerti, M.; Bay, S.; Franco Fraguas, L.; Osinaga, E. A Tn antigen binding lectin from Myrsine coriacea displays toxicity in human cancer cell lines. J. Nat. Med. 2013, 67, 247-254. [CrossRef] [PubMed]

65. Kulkarni, K.A.; Sinha, S.; Katiyar, S.; Surolia, A.; Vijayan, M.; Suguna, K. Structural basis for the specificity of basic winged bean lectin for the Tn-antigen: A crystallographic, thermodynamic and modelling study. FEBS Lett. 2005, 579, 6775-6780. [CrossRef] [PubMed]

66. Wu, A.M.; Wu, J.H.; Singh, T.; Hwang, P.Y.; Tsai, M.S.; Herp, A. Lectinochemical studies on the binding properties of a toxic lectin (ricin) isolated from the seeds of Ricinus communis. Chang Gung Med. J. 2005, 28, 530-542. [PubMed]

67. Wu, A.M.; Wu, J.H.; Singh, T.; Lai, L.J.; Yang, Z.; Herp, A. Recognition factors of Ricinus communis agglutinin I (RCA). Mol. Immunol. 2006, 43, 1700-1715. [CrossRef] [PubMed]

68. Vega, N.; Pérez, G. Isolation and characterization of a Salvia bogotensis seed lectin specific for the Tn antigen. Phytochemistry 2006, 67, 347-355. [CrossRef] [PubMed]

69. Piller, V.; Piller, F.; Cartron, J.P. Isolation and characterization of an $\mathrm{N}$-acetylgalactosamine specific lectin from Salvia sclarea seeds. J. Biol. Chem. 1986, 261, 14069-14075. [PubMed]

70. Medeiros, A.; Bianchi, S.; Calvete, J.J.; Balter, H.; Bay, S.; Robles, A.; Cantacuzène, D.; Nimtz, M.; Alzari, P.M.; Osinaga, E. Biochemical and functional characterization of the Tn-specific lectin from Salvia sclarea seeds. Eur. J. Biochem. 2000, 267, 1434-1440. [CrossRef] [PubMed]

71. Wu, A.M. Lectinochemical studies on the glyco-recognition factors of a Tn (GalNAc $\alpha 1 \rightarrow$ Ser/Thr) specific lectin isolated from the seeds of Salvia sclarea. J. Biomed. Sci. 2005, 12, 167-184. [CrossRef] [PubMed]

72. Moore, B.P.L.; Marsh, S.; Laschinger, C.; Simpson, S. Mixed-field polyagglutinability due to Tn: A further example. Transfusion 1975, 15, 54-57. [CrossRef] [PubMed]

73. Van Damme, E.J.M.; Barre, A.; Rougé, P.; van Leuven, F.; Peumans, W.J. The NeuAc( $\alpha-2,6)-G a l /$ GalNAc-binding lectin from elderberry (Sambucus nigra) bark, a type-2 ribosome-inactivating protein with an unusual specificity and structure. Eur. J. Biochem. 1996, 235, 128-137. [CrossRef] [PubMed]

74. Maveyraud, L.; Niwa, H.; Guillet, V.; Svergun, D.I.; Konarev, P.V.; Palmer, R.A.; Peumans, W.J.; Rougé, P.; van Damme, E.J.M.; Reynolds, C.D.; et al. Structural basis for sugar recognition, including the Tn carcinoma antigen, by the lectin SNA-II from Sambucus nigra. Proteins 2009, 75, 89-103. [CrossRef] [PubMed]

75. Peppa, V.I.; Venkat, H.; Kantsadi, A.L.; Inamdar, S.R.; Bhat, G.G.; Eligar, S.; Shivanand, A.; Chachadi, V.B.; Satisha, G.J.; Swamy, B.M.; et al. Molecular cloning, carbohydrate specificity and the crystal structure of two Sclerotium rolfsii lectin variants. Molecules 2015, 20, 10848-10865. [CrossRef] [PubMed]

76. Yadav, P.; Shahane, G.; Ramasamy, S.; Sengupta, D.; Gaikwad, S. Structural-functional insights and studies on saccharide binding of Sophora japonica seed lectin. Int. J. Biol. Macromol. 2016, 91, 75-84. [CrossRef] [PubMed]

77. Wu, A.M.; Wu, J.H.; Song, S.C.; Tsai, M.S.; Herp, A. Studies on the binding of wheat germ agglutinin (Triticum vulgaris) to O-glycans. FEBS Lett. 1998, 440, 315-319. [CrossRef]

78. Natsuka, S.; Kawaguchi, M.; Wada, Y.; Ichikawa, A.; Ikura, K.; Hase, S. Characterization of wheat germ agglutinin ligand on soluble glycoproteins in Caenothabditis elegans. J. Biochem. 2005, 135, 209-213. [CrossRef] [PubMed]

79. Sousa, B.L.; Silva Filho, J.C.; Kumar, P.; Pereira, R.I.; Łyskowski, A.; Rocha, B.A.; Delatorre, P.; Bezerra, G.A.; Nagano, C.S.; Gruber, K.; et al. High-resolution strycture of a new Tn antigen-binding lectin from Vatairea macrocarpa and a comparative analysis of Tn-binding legume lectins. Int. J. Biochem. Cell Biol. 2015, 59, 103-110. [CrossRef] [PubMed]

80. Uchide, N.; Ohyama, K.; Yamakawa, T.; Ohkuma, S. Presence of Vicia graminea lectin- or Vicia unijuga lectin-binding $(\mathrm{Vgu})$ glycoproteins, Vgu glycoproteins with Thomsen-Friedenreich (T) activity and T-reactive glycoproteins in human meconium. Int. J. Biochem. Cell Biol. 1995, 27, 319-327. [CrossRef] 
81. Tollefsen, S.; Kornfeld, R. The $\mathrm{B}_{4}$ lectin from Vicia villosa seeds Interacts with $N$-acetylgalactosamine residues $\alpha$-linked to serine or threonine residues in cell surface glycoproteins. J. Biol. Chem. 1983, 258, 5172-5176. [PubMed]

82. Wu, A.M.; Song, S.C.; Hwang, P.Y.; Wu, J.H.; Pfüller, U. Interaction of mistletoe toxic lectin-I with sialoglycoproteins. Biochem. Biophys. Res. Commun. 1995, 214, 396-402. [CrossRef] [PubMed]

83. Haji-Ghassemi, O.; Gilbert, M.; Spence, J.; Schur, M.J.; Parker, M.J.; Jenkins, M.L.; Burke, J.E.; van Faassen, H.; Young, N.M.; Evans, S.V. Molecular basis for recognition of cancer glycobiomarker, LacdiNAc (GalNAc $(\beta 1 \rightarrow 4)$ GlcNAc), by Wisteria floribunda agglutinin. J. Biol. Chem. 2016, 291, 24085-24095. [CrossRef] [PubMed]

84. Damian, L.; Fournier, D.; Winterhalter, M.; Paquereau, L. Determination of thermodynamic parameters of Xerocomus chrysenteron lectin interactions with $N$-acetylgalactosamine and Thomsen-Friedenreich antigen by isothermal titration calorimetry. BMC Biochem. 2005, 6, 11. [CrossRef] [PubMed]

85. Adwan, H.; Bayer, H.; Pervaiz, A.; Sagini, M.; Berger, M.R. Riproximin is a recently discovered type II ribosome inactivating protein with potential for treating cancer. Biotechnol. Adv. 2014, 32, 1077-1090. [CrossRef] [PubMed]

86. Osinaga, E.; Bay, S.; Tello, D.; Babino, A.; Pritsch, O.; Assemat, K.; Cantacuzene, D.; Nakada, H.; Alzari, P. Analysis of the fine specificity of Tn-binding proteins using synthetic glycopeptide epitopes and a biosensor based on surface plasmon resonance spectroscopy. FEBS Lett. 2000, 469, 24-28. [CrossRef]

87. Madariaga, D.; Martínez-Sáez, N.; Somovilla, V.J.; García-García, L.; Berbis, M.Á.; Valero-Gónzalez, J.; Martín-Santamaria, S.; Hurtado-Guerrero, R.; Asension, J.L.; Jiménez-Barbero, J.; et al. Serine versus threonine glycosylation with $\alpha$-O-GalNAc: Unexpected selectivity in their molecular recognition with lectins. Chemistry 2014, 20, 12616-12627. [CrossRef] [PubMed]

88. Delbaere, L.T.; Vandonselaar, M.; Prasad, L.; Quail, J.W.; Wilson, K.S.; Dauter, Z. Structures of the lectin IV of Griffonia simplicifolia and its complex with the Lewis b human blood group determinant at $2.0 \AA$ resolution. J. Mol. Biol. 1993, 230, 950-965. [CrossRef] [PubMed]

89. Madariaga, D.; Martinez-Sáez, N.; Somovilla, V.J.; Coelho, H.; Valero-González, J.; Castro-López, J.; Asension, J.L.; Jiménez-Barbero, J.; Busto, J.H.; Avenoza, A.; et al. Detection of tumor-associated glycopeptides by lectins: The peptide context modulates carbohydrate recognition. ACS Chem. Biol. 2015, 10, 747-756. [CrossRef] [PubMed]

90. Babino, A.; Tello, D.; Rojas, A.; Bay, S.; Osinaga, E.; Alzari, P.M. The crystal structure of a plant lectin in complex with the Tn antigen. FEBS Lett. 2003, 536, 106-110. [CrossRef]

91. Pettersen, E.F.; Goddard, T.D.; Huang, C.C.; Couch, G.S.; Greenblatt, D.M.; Meng, E.C.; Ferrin, T.E. UCSF Chimera-A visualization system for exploratory research and analysis. J. Comput. Chem. 2004, 25, 1605-1612. [CrossRef] [PubMed]

92. Jeyaprakash, A.A.; Geetha Rani, P.; Banuprakash Reddy, G.; Banumathi, S.; Betzel, C.; Sekar, K.; Surolia, A.; Vijayan, M. Crystal structure of the jacalin-T-antigen complex and a comparative study of lectin-T-antigen complexes. J. Mol. Biol. 2002, 321, 637-645. [CrossRef]

93. Nagae, M.; Nishi, N.; Nakamura-Tsuruta, S.; Hirabayashi, J.; Wakatsuki, S.; Kato, R. Structural analysis of the human galectin-9 $\mathrm{N}$-terminal carbohydrate recognition domain reveals unexpected properties that differ from the mouse orthologue. J. Mol. Biol. 2007, 375, 119-135. [CrossRef] [PubMed]

94. Springer, G.F. T and Tn pancarcinoma markers: Autoantigenic adhesion molecules in pathogenesis, prebiopsy carcinoma-detection, and long-term breast carcinoma immunotherapy. Crit. Rev. Oncog. 1995, 6, 57-85. [CrossRef] [PubMed]

95. Springer, G.F. Immunoreactive $\mathrm{T}$ and $\mathrm{Tn}$ epitopes in cancer diagnosis, prognosis, and immunotherapy. J. Mol. Med. 1997, 75, 594-602. [CrossRef] [PubMed]

96. Desai, P.R. Immunoreactive $\mathrm{T}$ and $\mathrm{Tn}$ antigens in malignancy: Role in carcinoma diagnosis, prognosis, and immunotherapy. Transfus. Med. Rev. 2000, 14, 312-325. [CrossRef] [PubMed]

97. Campo, E.; Condom, E.; Palacín, A.; Quesada, E.; Cardesa, A. Lectin binding patterns in normal and neoplastic colonic mucosa. Dis. Colon Rectum 1988, 31, 892-899. [CrossRef] [PubMed]

98. Calderó, J.; Campo, E.; Ascaso, C.; Ramos, J.; Panadés, M.J.; Reñé, J.M. Regional distribution of glycoconjugates in normal, transitional and neoplastic human colonic mucosa. A histochemical study using lectins. Virchows Arch. A Pathol. Anat. Histopathol. 1989, 415, 347-356. [CrossRef] [PubMed] 
99. Boland, C.R.; Martin, M.A.; Goldstein, I.J. Lectin reactivities as intermediate biomarkers in premalignant colorectal epithelium. J. Cell Biochem. Suppl. 1992, 16G, 103-109. [CrossRef] [PubMed]

100. Fucci, L.; Valentini, A.M.; Caruso, M.L. Can peanut agglutinin distinguish between pseudo and true invasion in coloic adenomas? Eur. J. Histochem. 1993, 37, 335-344. [PubMed]

101. Mazumdar, S.; SenGupta, S.K.; Param, R.; Sinha, S.N. Binding pattern of eight different lectins in healthy subjects and patients with dysplastic and malignant lesions of the oral cavity. Int. J. Oral Maxillofac. Surg. 1993, 22, 301-305. [CrossRef]

102. Brooks, S.A.; Leathem, A.J. Expression of $N$-acetyl galactosaminylated and sialylated glycans by metastases arising from primary breast cancer. Invasion Metastasis 1998, 18, 115-121. [CrossRef] [PubMed]

103. Springer, G.F. Tn epitope ( $N$-acetyl-D-galactosamine- $\alpha-O$-serine/threonine) density in primary breast carcinoma: A functional predictor of aggressiveness. Mol. Immunol. 1989, 26, 1-5. [CrossRef]

104. Yu, L.G. The oncofetal Thomsen-Fiedenreich carbohydrate antigen in cancer progession. Glycoconj. J. 2007, 24, 411-420. [CrossRef] [PubMed]

105. Sobrinho-Simões, M.; Damjanov, I. Lectin histochemistry of papillary and follicular carcinoma of the thyroid gland. Arch. Pathol. Lab. Med. 1986, 110, 722-729. [PubMed]

106. Fritz, P.; Dippon, J.; Kierschke, T.; Siegle, I.; Möhring, A.; Moisa, A.; Mürdter, T.E. Impact of mistletoe lectin binding in breast cancer. Anticancer Res. 2004, 24, 1187-1192. [PubMed]

107. Santaella-Verdejo, A.; Gallegos, N.; Pérez-Campos, E.; Hernández, P.; Zenteno, E. Use of Amaranthus leucocarpus lectin to differentiate cervical dysplasia (CIN). Prep. Biochem. Biotechnol. 2007, 37, 219-228. [CrossRef] [PubMed]

108. Li, S.; Mo, C.; Peng, Q.; Kang, X.; Sun, C.; Jiang, K.; Huang, L.; Lu, Y.; Sui, J.; Qin, X.; et al. Cell surface glycan alterations in epithelial mesenchymal transition process of Huh7 hepatocellular carcinoma cell. PLoS ONE 2013, 8, e71273. [CrossRef] [PubMed]

109. Feizi, T.; Fazio, F.; Chai, W.; Wong, C.H. Carbohydrate microarrays-A new set of technologies at the frontiers of glycomics. Curr. Opin. Struct. Biol. 2003, 13, 637-645. [CrossRef] [PubMed]

110. Angeloni, S.; Ridet, J.L.; Kusy, N.; Gao, H.; Crevoisier, F.; Guinchard, S.; Kochhar, S.; Sigrist, H.; Sprenger, N. Glycoprofiling with micro-arrays of glycoconjugates and lectins. Glycobiology 2005, 15, 31-41. [CrossRef] [PubMed]

111. Pilobello, K.T.; Krishnamoorthy, L.; Slawek, D.; Mahal, L.K. Development of a lectin microarray for the rapid analysis of protein glycopatterns. ChemBioChem 2005, 6, 985-989. [CrossRef] [PubMed]

112. Kuno, A.; Uchiyama, N.; Koseki-Kuno, S.; Ebe, Y.; Takashima, S.; Yamada, M.; Hirabayashi, J. Evanescent-field fluorescence-assisted lectin microarray: A new strategy for glycan profiling. Nat. Methods 2005, 2, 851-856. [CrossRef] [PubMed]

113. Manimala, J.C.; Li, Z.; Jain, A.; VedBrat, S.; Gildersleeve, J.C. Carbohydrate array analysis of anti-Tn antibodies and lectins reveals unexpected specificities: Implications for diagnostic and vaccine development. ChemBioChem 2005, 6, 2229-2241. [CrossRef] [PubMed]

114. Zhao, J.; Patwa, T.H.; Lubman, D.M.; Simeone, M. Protein biomarkers in cancer: Natural glycoprotein microarray approaches. Curr. Opin. Mol. Ther. 2008, 10, 602-610. [PubMed]

115. Syed, P.; Gidwani, K.; Kekki, H.; Leivo, J.; Pettersson, K.; Lamminmäki, U. Role of lectin microarrays in cancer diagnosis. Proteomics 2016, 16, 1257-1265. [CrossRef] [PubMed]

116. Dan, X.; Liu, W.; Ng, T.B. Development and applications of lectins as biological tools in biomedical research. Med. Res. Rev. 2016, 36, 221-247. [CrossRef] [PubMed]

117. Nakajima, K.; Inomata, M.; Iha, H.; Hiratsuka, T.; Etoh, T.; Shiraishi, N.; Kashima, K.; Kitano, S. Establishment of new predictive markers for distant reccurence of colorectal cancer using lectin microarray analysis. Cancer Med. 2015, 4, 293-302. [CrossRef] [PubMed]

118. Qiu, Y.; Patwa, T.H.; Xu, L.; Shedden, K.; Misek, D.E.; Tuck, M.; Jin, G.; Ruffin, M.T.; Turgeon, D.K.; Synal, S.; et al. Plasma glycoprotein profiling for colorectal cancer biomarker identification by lectin glycoarray and lectin blot. J. Proteome Res. 2008, 7, 1693-1703. [CrossRef] [PubMed]

119. Zhao, J.; Patwa, T.H.; Qiu, W.; Shedden, K.; Hinderer, R.; Misek, D.E.; Anderson, M.A.; Simeone, D.M.; Lubman, D.M. Glycoprotein microarrays with multi-lectin detection: Unique lectin binding patterns as a tool for classifying normal, chronic pancreatitis and pancreatic cancer sera. J. Proteome Res. 2007, 6, 1864-1874. [CrossRef] [PubMed] 
120. Yang, Z.; Harris, L.E.; Palmer-Toy, D.E.; Hancock, W.S. Multilectin affinity chromatography for characterization of multiple glycoprotein biomarker candidates in serum from breast cancer patients. Clin. Chem. 2006, 52, 1897-1905. [CrossRef] [PubMed]

121. Li, X.; Guan, F.; Li, D.; Tan, Z.; Yang, G.; Wu, Y.; Huang, Z. Identification of aberrantly expressed glycans in gastric cancer by integrated lectin microarray and mass spectrometric analyses. Oncotarget 2016, 52, 87284-87300. [CrossRef] [PubMed]

122. Nishijima, Y.; Toyoda, M.; Yamazaki-Inoue, M.; Sugiyama, T.; Miyazawa, M.; Muramatsu, T.; Nakamura, K.; Narimatsu, H.; Umezawa, A.; Mikami, M. Glycan profiling of endometrial cancers using lectin microarray. Genes Cells 2012, 17, 826-836. [CrossRef] [PubMed]

123. Huang, W.L.; Li, Y.G.; Lv, Y.C.; Guan, X.H.; Ji, H.F.; Chi, B.R. Use of lectin microarray to differentiate gastric cancer from gastric ulcer. World J. Gastroenterol. 2014, 20, 5474-5482. [CrossRef] [PubMed]

124. Matsuda, A.; Kuno, A.; Nakagawa, T.; Ikehara, Y.; Irimura, T.; Yamamoto, M.; Nakanuma, Y.; Miyoshi, E.; Nakamori, S.; Nakanishi, H.; et al. Lectin microarray-based sero-biomarker verification targeting aberrant O-linked glycosylation on mucin 1. Anal. Chem. 2015, 87, 7274-7281. [CrossRef] [PubMed]

125. Šunderić, M.; Šedivá, A.; Robajac, D.; Miljuš, G.; Gemeiner, P.; Nedicć, O.; Katrlík, J. Lectin-based protein microarray analysis of differences in serum $\alpha 2$-macroglobulin glycosylation between patients with colorectal cancer and persons without cancer. Biotechnol. Appl. Biochem. 2016, 63, 457-464. [CrossRef] [PubMed]

126. Hirao, Y.; Matsuzaki, H.; Iwaki, J.; Kuno, A.; Kaji, H.; Ohkura, T.; Togayachi, A.; Abe, M.; Nomura, M.; Noguchi, M.; et al. Glycoproteomics approach for identifying glycobiomarker canditate molecules for tissue type classification of non-small cell lung carcinoma. J. Proteome Res. 2014, 13, 4705-4716. [CrossRef] [PubMed]

127. Roy, B.; Chattopadhyay, G.; Misrha, D.; Das, T.; Chakraborty, S.; Maiti, T.K. On-chip lectin microarray for glycoprofiling of different gastritis types and gastric cancer. Biomicrofluidics 2014, 8, 034107. [CrossRef] [PubMed]

128. Fry, S.; Afrough, B.; Lomax-Browne, H.J.; Timms, J.F.; Velentzis, L.S.; Leathem, A.J.C. Lectin microarray profiling of metastatic breast cancer. Glycobiology 2011, 21, 1060-1070. [CrossRef] [PubMed]

129. Fry, S.; Afrough, B.; Leathem, A.; Dwek, M. Lectin array-based strategies for identifying metastasis-associated changes in glycosylation. Methods Mol. Biol. 2012, 878, 267-272. [PubMed]

130. He, J.; Liu, Y.; Xie, X.; Zhu, T.; Soules, M.; DiMeco, F.; Vescovi, A.L.; Fan, X.; Lubman, D.M. Identification of cell surface glycoprotein markers for glioblastoma-derived stem-like cells using a lectin microarray and LC-MS/MS approach. J. Proteome Res. 2010, 9, 2565-2572. [CrossRef] [PubMed]

131. Konska, G.; Guerry, M.; Caldefie-Chezet, F.; de Latour, M.; Guillot, J. Study of the expression of Tn antigen in different types of human breast cancer cells using VVA-B 4 lectin. Oncol. Rep. 2006, 15, 305-310. [CrossRef] [PubMed]

132. Kawaguchi, T.; Takazawa, H.; Imai, S.; Morimoto, J.; Watanabe, T.; Kanno, M.; Igarashi, S. Expression of Vicia villosa agglutinin (VVA)-binding glycoprotein in primary breast cancer in relation to lymphatic metastasis: Is atypical MUC1 bearing Tn antigen a receptor of VVA? Breast Cancer Res. Treat. 2006, 98, 31-43. [CrossRef] [PubMed]

133. Singh, R.; Campbell, B.J.; Yu, L.G.; Fernig, D.G.; Milton, J.D.; Goodlad, R.A.; FitzGerald, A.J.; Rhodes, J.M. Cell surface-expressed Thomsen-Friedenreich antigen in colon cancer is predominantly carried on high molecular weight splice variants of CD44. Glycobiology 2001, 11, 587-592. [CrossRef] [PubMed]

134. Shio, Y.; Suzuki, H.; Kawaguchi, T.; Ohsugi, J.; Higuchi, M.; Fujiu, K.; Kanno, R.; Ohishi, A.; Gotoh, M. Carbohydrate status detecting by PNA is changeable through cancer prognosis from primary to metastatic nodal site: A possible prognostic factor in patient with node-positive lung adenocarcinoma. Lung Cancer 2007, 57, 187-192. [CrossRef] [PubMed]

135. Futsukaichi, T.; Etoh, T.; Nakajima, K.; Daa, T.; Shiroshita, H.; Shiraishi, N.; Kitano, S.; Inomata, M. Decreased expression of Bauhinia purpurea lectin is a predictor of gastric cancer recurrence. Surg. Today 2015, 45, 1299-1306. [CrossRef] [PubMed]

136. Yamashita, K.; Kuno, A.; Ikehata, Y.; Katada, N.; Hirabayashi, J.; Narimatsu, H.; Watanabe, M. Lectin microarray technology identifies specific lectins related to lymp node metastasis of advanced gastric cancer. Gastric Cancer 2016, 19, 531-542. [CrossRef] [PubMed] 
137. Liang, Y.; Chen, H.; Zhang, H.B.; Jin, Y.X.; Guo, H.Q.; Chen, X.G.; Sun, H. Lectin from Agrocybe aegerita as a glycophenotype probe for evaluation of progression and survival in colorectal cancer. Asian Pac. J. Cancer Prev. 2014, 15, 5601-5605. [CrossRef] [PubMed]

138. Zhou, S.M.; Cheng, L.; Guo, S.J.; Wang, Y.; Czajkowsky, D.M.; Gao, H.; Hu, X.F.; Tao, S.C. Lectin RECA-I specifically binds to metastasis-associated cell surface glycan in triple-negative breast cancer. Breast Cancer Res. 2015, 17, 36. [CrossRef] [PubMed]

139. Li, C.; Simeone, D.M.; Brenner, D.E.; Anderson, M.A.; Shedden, K.A.; Ruffin, M.T.; Lubman, D.M. Pancreatic cancer serum detection using a lectin/glyco-antibody array method. J. Proteome Res. 2009, 8, 483-492. [CrossRef] [PubMed]

140. Sasaki, R.; Yamasaki, K.; Abiru, S.; Komori, A.; Nagaoka, S.; Saeki, A.; Hashimoto, S.; Bekki, S.; Kugiyama, Y.; Kuno, A.; et al. Serum Wisteria floribunda agglutinin-positive Mac-2 binding protein values predict the development of hepatocellular carcinoma among patients with chronic hepatitis $\mathrm{C}$ after sustained virological response. PLoS ONE 2015, 10, e129053. [CrossRef] [PubMed]

141. Lyu, S.Y.; Choi, S.H.; Park, W.B. Korean mistletoe lectin-induced apoptosis in hepatocarcinoma cells is associated with inhibition of telomerase via mitochondrial controlled pathway idependent of p53. Arch. Pharm. Res. 2002, 25, 93-101. [CrossRef] [PubMed]

142. De Mejía, E.G.; Prisecaru, V.I. Lectins as bioactive plant proteins: A potential in cancer treatment. Crit. Rev. Food Sci. Nutr. 2005, 45, 425-445. [CrossRef] [PubMed]

143. Fu, L.L.; Zhou, C.C.; Yao, S.; Yu, J.Y.; Liu, B.; Bao, J.K. Plant lectins: Targeting programmed cell death pathways as antitumor agents. Int. J. Biochem. Cell Biol. 2011, 43, 1442-1449. [CrossRef] [PubMed]

144. Yau, T.; Dan, X.; Ng, C.C.W.; Ng, T.B. Lectins with potential for anti-cancer therapy. Molecules 2015, 20, 3791-3810. [CrossRef] [PubMed]

145. Jiang, Q.L.; Zhang, S.; Tian, M.; Zhang, S.Y.; Xie, T.; Chen, D.Y.; Chen, Y.J.; He, J.; Liu, J.; Ouyang, L.; et al. Plant lectins, from ancient sugar-binding proteins to emerging anti-cancer drugs in apoptosis and autophagy. Cell Prolif. 2015, 48, 17-28. [CrossRef] [PubMed]

146. Shang, C.; Chen, Q.; Dell, A.; Haslam, S.M.; de Vos, W.H.; van Damme, E.J.M. The cytotoxicity of elderberry ribosome-inactivating proteins is not solely determined by their protein translation inhibition activity. PLoS ONE 2015, 10, e0132389. [CrossRef] [PubMed]

147. De Virgilio, M.; Lombardi, A.; Caliandro, R.; Fabbrini, M.S. Ribosome-inactivating proteins: From plant defense to tumor attack. Toxins 2010, 2, 2699-2737. [CrossRef] [PubMed]

148. Mishra, R.; Kumar, M.S.; Karande, A.A. Inhibition of protein synthesis leading to unfolded protein response is the major event in abrin-mediated apoptosis. Mol. Cell Biochem. 2015, 403, 255-265. [CrossRef] [PubMed]

149. Li, L.N.; Zhang, H.D.; Zhi, R.; Yuan, S.J. Down-regulation of some miRNA by degrading their precursors contributes to anti-cancer effect of mistletoe lectin-I. Br. J. Pharmacol. 2011, 162, 349-364. [CrossRef] [PubMed]

150. Fu, L.L.; Zhao, X.; Xu, H.L.; Wen, X.; Wang, S.Y.; Liu, B.; Bao, J.K.; Wei, Y.Q. Identification of microRNA-regulated autophagic pathways in plant lectin-induced cancer cell death. Cell Prolif. 2012, 45, 477-485. [CrossRef] [PubMed]

151. Barkeer, S.; Guha, N.; Hothpet, V.; Saligrama Adavigowda, D.; Hegde, P.; Padmanaban, A.; Yu, L.G.; Swamy, B.M.; Inamdar, S.R. Molecular mechanism of anticancer effect of Sclerotium rolfsii lectin in HT29 cells involves differential expression of genes associated with multiple signaling pathways: A microarray analysis. Glycobiology 2015, 25, 1375-1391. [CrossRef] [PubMed]

152. Shi, Z.; Sun, R.; Yu, T.; Liu, R.; Cheng, L.J.; Bao, J.K.; Zou, L.; Tang, Y. Identification of novel pathways in plant lectin-induced cancer cell apoptosis. Int. J. Mol. Sci. 2016, 17, 228. [CrossRef] [PubMed]

153. Yu, L.; Fernig, D.G.; Smith, J.A.; Milton, J.D.; Rhodes, J.M. Reversible inhibition of proliferation of epithelial cell lines by Agaricus bisporus (edible mushroom) lectin. Cancer Res. 1993, 53, 4627-4632. [PubMed]

154. Loréa, P.; Goldschmidt, D.; Darro, F.; Salmon, I.; Bovin, N.; Gabius, H.J.; Kiss, R.; Danguy, A. In vitro characterization of lectin-induced alterations on the proliferative activity of three human melanoma cell lines. Melanoma Res. 1997, 7, 353-363. [CrossRef] [PubMed]

155. Wang, H.; Ng, T.B.; Ooi, V.E.C.; Liu, W.K. Effects of lectins with different carbohydrate-binding specificities on hepatoma, choriocarcinoma, melanoma and osteosarcoma cell lines. Int. J. Biochem. Cell Biol. 2000, 32, 365-372. [CrossRef] 
156. Sahasrabuddhe, A.A.; Ahmed, N.; Krishnasastry, M.V. Stress-induced phosphorylation of caveolin-1 and p38, and down-regulation of EGFr and ERK by the dietary lectin jacalin in two human carcinoma cell lines. Cell Stress Chaperones 2006, 11, 135-147. [CrossRef] [PubMed]

157. Kabir, S.R.; Nabi, M.M.; Nurujjaman, M.; Abu Reza, M.; Alam, A.H.; Zaman, R.; Khalid-Bin-Ferdaus, K.M.; Amin, R.; Khan, M.M.; Hossain, M.A.; et al. Momordica charantia seed lectin: Toxicity, bacterial agglutination and antitumor properties. Appl. Biochem. Biotechnol. 2015, 175, 2616-2628. [CrossRef] [PubMed]

158. Fang, E.F.; Zhang, C.Z.Y.; Ng, T.B.; Wong, J.H.; Pan, W.L.; Ya, W.J.; Chan, Y.S.; Fong, W.P. Momordica charantia lectin, a type II ribosome inactivating protein, exhibits antitumor activity toward human nasopharyngeal carcinoma cells in vitro and in vivo. Cancer Prev. Res. 2012, 5, 109-121. [CrossRef] [PubMed]

159. Fan, X.; He, L.; Meng, Y.; Li, G.; Li, L.; Meng, Y. A-MMC and MAP30, two ribosome-inactivating proteins extracted from Momordica charantia, induce cell cycle arrest and apoptosis in A549 human lung carcinoma cells. Mol. Med. Rep. 2015, 11, 3553-3558. [CrossRef] [PubMed]

160. Schumacher, U.; Stamouli, A.; Adam, E.; Peddie, M.; Pfüller, U. Biochemical, histochemical and cell biological investigations on the action of mistletoe lectins I, II and III with human breast cancer cell lines. Glycoconj. J. 1995, 12, 250-257. [CrossRef] [PubMed]

161. Griffin, T.W.; Yaynes, L.R.; DeMartino, J.A. Selective cytotoxicity of a ricin A-chain-anti-carcinoembryonic antigen antibody conjugate for a human colon adenocarcinoma cell line. J. Natl. Cancer Inst. 1982, 69, 799-805. [PubMed]

162. Tsukazaki, K.; Hayman, E.G.; Ruoslahti, E. Effects of ricin A chain conjugates of monoclonal antibodies to human $\alpha$-fetoprotein and placental alkaline phosphatase on antigen-producing tumor cells in culture. Cancer Res. 1985, 45, 1834-1838. [PubMed]

163. Ohba, H.; Bakalova, R. Relationships between degree of binding, cytotoxicity and cytoagglutinating activity of plant-derived agglutinins in normal lymphocytes and cultured leukemic cell lines. Cancer Chemother. Pharmacol. 2003, 51, 451-458. [PubMed]

164. Savanur, M.A.; Eligar, S.M.; Pujari, R.; Chen, C.; Mahajan, P.; Borges, A.; Shastry, P.; Ingle, A.; Kalraiya, R.D.; Swamy, B.M.; et al. Sclerotium rolfsii induces stronger inhibition of proliferation in human breast cancer cells than normal human mammary epithelial cells by induction of cell apoptosis. PLoS ONE 2014, 9, e110107. [CrossRef] [PubMed]

165. Narayanan, S.; Surolia, A.; Karande, A.A. Ribosome-inactivating protein and apoptosis: Abrin causes cell death via mitochondrial pathway in Jurkat cells. Biochem. J. 2004, 377, 233-240. [CrossRef] [PubMed]

166. Behera, B.; Misrha, D.; Roy, B.; Devi, K.S.; Narayan, R.; Das, J.; Ghosh, S.K.; Maiti, T.K. Abrus precatorius agglutinin-derived peptides induce ROS-dependent mitochondrial apoptosis through JNK and Akt/P3/P53 pathways in HeLa cells. Chem. Biol. Interact. 2014, 222, 97-105. [CrossRef] [PubMed]

167. Yu, Y.; Yang, R.; Zhao, X.; Qin, D.; Liu, Z.; Liu, F.; Song, X.; Li, L.; Feng, R.; Gao, N. Abrin P2 suppresses proliferation and induces apoptosis of colon cancer cells via mitochondrial membrane depolarization and caspase activation. Acta Biochim. Biophys. Sin. 2016, 48, 420-429. [CrossRef] [PubMed]

168. Bhutia, S.K.; Behera, B.; Das, D.N.; Mukhopadhyay, S.; Sinha, N.; Panda, P.K.; Naik, P.P.; Patra, S.K.; Mandal, M.; Sarkar, S.; et al. Abrus agglutinin is a potent anti-proliferative and anti-angiogenic agent in human breast cancer. Int. J. Cancer 2016, 139, 457-466. [CrossRef] [PubMed]

169. Mukhopahyay, S.; Panda, P.K.; Behera, B.; Das, C.K.; Hassan, M.K.; Das, D.N.; Sinha, N.; Bissoyi, A.; Pramanik, K.; Maiti, T.K.; et al. In vitro and in vivo antitumor effects of peanut agglutinin through induction of apoptotic and autophagic cell death. Food Chem. Toxicol. 2014, 64, 369-377. [CrossRef] [PubMed]

170. Silva, M.C.; de Paula, C.A.; Ferreira, J.G.; Paredes-Gamero, E.J.; Vaz, A.M.; Sampaio, M.U.; Correia, M.T.; Oliva, M.L. Bauhinia forficata lectin (BfL) induces cell death and inhibits integrin-mediated adhesion on MCF7 human breast cancer cells. Biochim. Biophys. Acta 2014, 1840, 2262-2271. [CrossRef] [PubMed]

171. Panda, P.K.; Mukhopadhyay, S.; Behera, B.; Bhol, C.S.; Day, S.; Das, D.N.; Sinha, N.; Bissoyi, A.; Pramanik, K.; Maiti, T.K.; et al. Antitumor effect of soybean lectin mediated through reactive oxygen species-dependent pathway. Life Sci. 2014, 111, 27-35. [CrossRef] [PubMed]

172. Zhang, C.Z.; Fang, E.F.; Zhang, H.T.; Liu, L.L.; Yun, J.P. Momordica charantia lectin exhibits antitumor activity towards hepatocellular carcinoma. Investig. New Drugs 2015, 33, 1-11. [CrossRef] [PubMed]

173. Fang, E.F.; Zhang, C.Z.; Wong, J.H.; Shen, J.Y.; Li, C.H.; Ng, T.B. The MAP30 protein from bitter gourd (Momordica charantia) seeds promotes apoptosis in liver cancer cells in vitro and in vivo. Cancer Lett. 2012, 324, 66-74. [CrossRef] [PubMed] 
174. Chowdhury, S.R.; Ray, U.; Chatterjee, B.; Roy, S.B. Targeted apoptosis in ovarian cancer cells through mitochondrial dysfunction in response to Sambucus nigra agglutinin. Cell Death Dis. 2017, 8, e2762. [CrossRef] [PubMed]

175. Zwierzina, H.; Bergmann, L.; Fiebig, H.; Aamdal, S.; Schoffski, P.; Vitthohm, K.; Leutzen, H. The preclinical and clinical activity of aviscumine: A potential anticancer drug. Eur. J. Cancer 2011, 47, 1450-1457. [CrossRef] [PubMed]

176. Han, S.Y.; Hong, C.E.; Kim, H.G.; Lyu, S.Y. Anti-cancer effects of enteric-coated polymers containing mistletoe lectin in murine melanoma cells in vitro and in vivo. Mol. Cell Biochem. 2015, 408, 73-87. [CrossRef] [PubMed]

177. Tyagi, N.; Tyagi, M.; Pachauri, M.; Ghosh, P.C. Potential therapeutic applications of plant toxin-ricin in cancer: Challenges and advances. Tumour Biol. 2015, 36, 8239-8246. [CrossRef] [PubMed]

178. Liao, P.; Liu, W.; Li, H.; Gao, H.; Wang, H.; Li, N.; Xu, N.; Li, J.; Wan, J.; Liu, L.; et al. Morphological changes of ricin toxin-induced apoptosis in human cervical cancer cells. Toxicol. Ind. Health 2012, 28, $439-448$. [CrossRef] [PubMed]

179. Horrix, C.; Raviv, Z.; Flescher, E.; Voss, C.; Berger, M.R. Plant ribosome-inactivating proteins type II induce the unfolded protein response in human cancer cells. Cell Mol. Life Sci. 2011, 68, 1269-1281. [CrossRef] [PubMed]

180. Kim, M.S.; So, H.S.; Lee, K.M.; Park, J.S.; Lee, J.H.; Moon, S.K.; Ryu, D.G.; Chung, S.Y.; Jung, B.H.; Kim, Y.K.; et al. Activation of caspase cascades in Korean mitletoe (Viscum album var. coloratum) lectin-II-induced apoptosis of human myeloleukemic U937 cells. Gen. Pharmacol. 2000, 34, 349-355. [CrossRef]

181. Kim, M.S.; Lee, J.; Lee, K.M.; Yang, S.H.; Choi, S.; Chung, S.Y.; Kim, T.Y.; Jeong, W.H.; Park, R. Involvement of hydrogen peroxide in mistletoe lectin-II-induced apoptosis of myeloleukemic U937 cells. Life Sci. 2003, 73, 1231-1243. [CrossRef]

182. Choi, S.H.; Lyu, S.Y.; Park, W.B. Mistletoe lectin induces apoptosis and telomerase inhibition in human A253 cancer cells through dephosphorylation of Akt. Arch. Pharm. Res. 2004, 27, 68-76. [CrossRef] [PubMed]

183. Twardziok, M.; Kleinsimon, S.; Rolff, J.; Jäger, S.; Eggert, A.; Seifert, G.; Delebinski, C.I. Multiple active compounds from Viscum album L. synergistically converge to promote apoptosis in Ewing sarcoma. PLoS ONE 2016, 11, e0159749. [CrossRef] [PubMed]

184. Twardziok, M.; Meierhofer, D.; Börno, B.; Timmermann, B.; Jäger, S.; Boral, S.; Eggert, A.; Delebinski, C.I.; Seifert, G. Transcriptomic and proteomic insight into the effects of a defined European mistletoe extract in Ewing sarcoma cells reveals cellular stress responses. BMC Complement. Altern. Med. 2017, $17,237$. [CrossRef] [PubMed]

185. Pervaiz, A.; Zepp, M.; Adwan, H.; Berger, M.R. Riproximin modulates multiple signaling cascades leading to cytostatic and apoptotic effects in human breast cancer cells. J. Cancer Res. Clin. Oncol. 2016, 142, 135-147. [CrossRef] [PubMed]

186. Ditamo, Y.; Rupil, L.L.; Sendra, V.G.; Nores, G.A.; Roth, G.A.; Irazoqui, F.J. In vivo immunomodulatory effect of the lectin from edible mushroom Agaricus bisporus. Food Funct. 2016, 7, 162-269. [CrossRef] [PubMed]

187. Bocci, V. Mistletoe (Viscum album) lectins as cytokine inducers and immunoadjuvant in tumor therapy. A review. J. Biol. Regul. Homeost. Agents 1993, 7, 1-6. [PubMed]

188. Hajto, T.; Hostanka, K.; Weber, K.; Zinke, H.; Fischer, J.; Mengs, U.; Lentzen, H.; Saller, R. Effect of a recombinant lectin, Viscum album agglutinin, on the secretion of interleukin-12 in cultured human peripheral blood mononuclear cells and on NK-cell-mediated cytotoxicity of rat splenocytes in vitro and in vivo. Nat. Immunol. 1998, 16, 34-46. [CrossRef]

189. Hostanka, K.; Hajto, T.; Spagnoli, G.C.; Fischer, J.; Lentzen, H.; Herrmann, R. A plant lectin derived from Viscum album induces cytokine gene expression and protein production in cultures of human peripheral blood mononuclear cells. Nat. Immunol. 1995, 14, 295-304.

190. Lyu, S.Y.; Park, W.B. Mistletoe lectin transport by M-cells in follicle-associated epithelium (FAE) and IL-12 secretion in dendritic cells situated below FAE in vitro. Arch. Pharm. Res. 2010, 33, 1433-1441. [CrossRef] [PubMed]

191. Chan, Y.S.; Xia, L.; Ng, T.B. White kidney bean lectin exerts anti-proliferative and apoptotic effects on cancer cells. Int. J. Biol. Macromol. 2016, 85, 335-345. [CrossRef] [PubMed] 
192. Souza, M.A.; Carvalho, F.C.; Ruas, L.P.; Ricci-Azevedo, R.; Roque-Barreira, M.C. The immunomodulatory effects of plant lectins: A review with emphasis on artinM properties. Glycoconj. J. 2013, 30, 641-657. [CrossRef] [PubMed]

193. Akhlynina, T.V.; Gulak, P.V.; Serebriakova, N.V.; Rozenkrants, A.A.; Sobolev, A.S. Photodynamic effects of a concanavalin A-chlorin e6 conjugate on human fibroblasts [Article in Russian]. Biull. Eksp. Biol. Med. 1990, 109, 150-152. [CrossRef] [PubMed]

194. Komath, S.S.; Kavitha, M.; Swamy, M.J. Beyond carbohydrate binding: New directions in plant lectin research. Org. Biomol. Chem. 2006, 4, 973-988. [CrossRef] [PubMed]

195. Komath, S.S.; Bhanu, K.; Maiya, B.G.; Swamy, M.J. Binding of porphyrin by the tumor-specific lectin, jacalin [Jack fruit (Artocarpus integrifolia) agglutinin]. Biosci. Rep. 2000, 20, 265-276. [CrossRef] [PubMed]

196. Komath, S.S.; Kenoth, R.; Giribabu, L.; Maiya, B.G.; Swamy, M.J. Fluorescence and absorption spectroscopic studies on the interaction of porphyrins with snake gourd (Trichosanthes anguina) seed lectin. J. Photochem. Photobiol. B Biol. 2000, 55, 49-55. [CrossRef]

197. Sultan, N.A.M.; Maiya, B.G.; Swamy, M.J. Thermodynamic analysis of porphyrin binding to Momordica charantia (bitter gourd) lectin. Eur. J. Biochem. 2004, 271, 3274-3282. [CrossRef] [PubMed]

198. Goel, M.; Damai, R.S.; Sethi, D.K.; Kaur, K.J.; Maiya, B.G.; Swamy, M.J.; Salunke, D.M. Crystal structure of the PNA-porphyrin complex in the presence and absence of lactose: Mapping of the conformational changes on lactose binding, interacting surfaces, and supramolecular aggregations. Biochemistry 2005, 44, 5588-5596. [CrossRef] [PubMed]

199. Pandey, G.; Fatma, T.; Komath, S.S. Specific interaction of the legume lectins, concanavalin A and peanut agglutinin, with phycocyanin. Photochem. Photobiol. 2009, 85, 1126-1133. [CrossRef] [PubMed]

200. Kavitha, M.; Swamy, M.J. Thermodynamic studies on the interaction of water soluble porphyrins with the glucose/mannose-specific lectin from garden pea (Pisum sativum). Life 2006, 58, 720-730. [CrossRef] [PubMed]

201. Pandey, G.; Fatma, T.; Cowsik, S.M.; Komath, S.S. Specific interaction of jacalin with phycocyanin, a fluorescent phycobiliprotein. J. Photochem. Photobiol. B Biol. 2009, 97, 87-93. [CrossRef] [PubMed]

202. D'Auria, S.; Petrova, L.; John, C.; Russev, G.; Varriale, A.; Bogoeva, V. Tumor-specific protein human galectin-1 interacts with anticancer agents. Mol. BioSyst. 2009, 5, 1331-1336. [CrossRef] [PubMed]

203. Poiroux, G.; Pitié, M.; Culerrier, R.; Ségui, B.; van Damme, E.J.M.; Peumans, W.J.; Bernadou, J.; Levade, T.; Rougé, P.; Barre, A.; et al. Morniga G: A plant lectin as an endocytic ligand for photosensitizer molecule targeting toward tumor-associated T/Tn antigens. Photochem. Photobiol. 2011, 87, 370-377. [CrossRef] [PubMed]

204. Poiroux, G.; Pitié, M.; Culerrier, R.; Lafont, E.; Ségui, B.; van Damme, E.J.M.; Peumans, W.J.; Bernadou, J.; Levade, T.; Rougé, P.; et al. Targeting of T/Tn antigens with a plant lectin to kill human leukemia cells by photochemotherapy. PLoS ONE 2011, 6, e23315. [CrossRef] [PubMed]

205. Evangelio, E.; Poiroux, G.; Culerrier, R.; Pratviel, G.; van Damme, E.J.M.; Peumans, W.J.; Barre, A.; Rougé, P.; Benoist, H.; Pitié, M. Comparative study of the phototoxicity of long-wavelength photosensitizers targeted by the Morniga G lectin. Bioconjug. Chem. 2011, 22, 1337-1344. [CrossRef] [PubMed]

206. Kejík, Z.; Bříza, T.; Králová, J.; Potčková, P.; Král, A.; Martásek, P.; Král, V. Coordination conjugates of therapeutic proteins with drug carriers: A new approach for versatile advanced drug delivery. Bioorg. Med. Chem. Lett. 2011, 21, 5514-5520. [CrossRef] [PubMed]

207. Obaid, G.; Chambrier, I.; Cook, M.J.; Russell, D.A. Targeting the oncofetal Thomsen-Friedenreich disaccharide using jalaclin-PEG phthalocyanine gold nanoparticles for photodynamic cancer therapy. Angew. Chem. Int. Ed. 2012, 51, 6158-6162. [CrossRef] [PubMed]

208. Obaid, G.; Chambrier, I.; Cook, M.J.; Russell, D.A. Cancer targeting with biomolecules: A comparative study of photodynamic therapy efficacy using antibody or lectin conjugated phthalocyanine-PEG gold nanoparticles. Photochem. Photobiol. Sci. 2015, 14, 737-747. [CrossRef] [PubMed]

209. Hockl, P.F.; Wolosiuk, A.; Pérez-Sáez, J.M.; Bordoni, A.V.; Croci, D.O.; Toum-Terrones, Y.; Soler-Illia, G.J. Glyco-nano-oncology: Novel therapeutic opportunities by combining small and sweet. Pharmacol. Res. 2016, 109, 45-54. [CrossRef] [PubMed]

210. Benoist, H.; Culerrier, R.; Poiroux, G.; Ségui, B.; Jauneau, A.; van Damme, E.J.M.; Peumans, W.J.; Barre, A.; Rougé, P. Two structurally identical mannose-specific jacalin-related lectins display different effects on human T lymphocytes activation and cell death. J. Leukoc. Biol. 2009, 86, 103-114. [CrossRef] [PubMed] 
211. Pereira, P.M.R.; Silva, S.; Cavaleiro, J.A.S.; Ribeiro, C.A.F.; Tomé, J.P.C.; Fernandes, R. Galactodendritic phthalocyanine targets carbohydrate-binding proteins enhancing photodynamic therapy. PLoS ONE 2014, 9, e95529. [CrossRef] [PubMed]

212. Vrouenraets, M.B.; Visser, G.W.; Snow, G.B.; van Dongen, G.A. Basic principles, applications in oncology and improved selectivity of photodynamic therapy. Anticancer Res. 2003, 23, 505-522. [PubMed]

213. Sibata, C.H.; Colussi, V.C.; Oleinick, N.L.; Kinsella, T.J. Photodynamic therapy in oncology. Expert Opin. Pharmacother. 2001, 2, 917-927. [PubMed]

214. Gudgin Dickson, E.F.; Goyan, R.L.; Pottier, R.H. New directions in photodynamic therapy. Cell. Mol. Biol. 2002, 48, 939-954. [PubMed]

(C) 2017 by the authors. Licensee MDPI, Basel, Switzerland. This article is an open access article distributed under the terms and conditions of the Creative Commons Attribution (CC BY) license (http:/ / creativecommons.org/licenses/by/4.0/). 